\title{
Aid for health, economic growth, and the emigration of medical workers
}

\section{Mauro Lanati ${ }^{1}$ (D) | Rainer Thiele ${ }^{2}$}

\author{
${ }^{1}$ Migration Policy Centre (RSCAS), European \\ University Institute, Florence, Italy \\ ${ }^{2}$ Research Center "Poverty Reduction, Equity \\ and Development", Kiel Institute for the \\ World Economy, Kiel, Germany

\section{Correspondence} \\ Mauro Lanati, MEDAM Research Fellow, \\ Migration Policy Centre (RSCAS), European \\ University Institute, Villa Malafrasca, Via \\ Boccaccio 151, Florence I-50133, Italy. \\ Email: mauro.lanati@eui.eu \\ Funding information \\ Stiftung Mercator, Grant/Award Number: PN \\ 14-297
}

\begin{abstract}
Debates on the extent to which developing countries suffer from a brain drain often focus on the emigration of locally scarce health personnel. In this paper, we empirically examine how two potential determinants-aid for health and local income levels-affect the emigration rates of doctors and nurses from developing countries. Employing a standard gravity model of international migration, we show that aid for health has a negative effect on the emigration of both nurses and doctors. Our findings suggest that donors influence the emigration decisions of doctors and nurses through improvements in health infrastructure. Higher income per capita is also associated with lower emigration from developing countries for doctors and nurses alike. Given that nurses typically belong to the poorer segments of populations in the countries of origin, we can conclude that even at low initial income levels, on balance, economic growth provides an incentive to stay.

\section{KEYWORDS}

aid, development, health personnel, migration

JEL CLASSIFICATION

F22; F35; O15
\end{abstract}




\section{1 | INTRODUCTION}

South-north migration of skilled people has become an increasingly important phenomenon over the past few decades, with the number of high-skilled migrants residing in member countries of the OECD growing at a much faster rate than the respective number of low-skilled migrants (Botezat \& Ramos, 2020). The early literature on skilled workers' emigration concluded that it is likely to cause a brain drain, exerting an adverse effect on the welfare of the people who stay in the countries of origin (e.g., Bhagwati \& Hamada, 1974). More recently, it has been argued that skilled migration may also contribute to long-term local development, the most relevant transmission mechanism being that emigration possibilities for skilled workers encourage the accumulation of human capital in the migrantsending countries (e.g., Stark et al., 1997).

Medical workers are among the most mobile skilled professions. Their emigration may give rise to large welfare losses given the scarcity of health personnel in many developing countries. According to the World Health Organisation (WHO, 2020), more than $40 \%$ of WHO Member States have fewer than 10 medical doctors available per 10000 population, whereas over $55 \%$ have less than 40 nurses and midwives per 10000 population. Empirical studies have shown that the emigration of doctors is associated with high HIV death rates, child mortality and too few medical workers to meet basic healthcare needs at the local level, pointing to a medical brain drain (see Astor et al., 2005; Bhargava \& Docquier, 2008; Chauvet et al., 2013). Yet, the literature also suggests instances where emigration prospects for medical workers provide incentives for investment in education that are sufficiently high to bring about a net welfare gain for the country of origin (e.g., Abarcar \& Theoharides, 2020; Kangasniemi et al., 2007). Despite this empirical ambiguity, there appears to be a justification for the international community to support developing countries in retaining medical workers through improved local conditions. It has been pointed out (e.g., Clemens \& McKenzie, 2009) that a lack of medical infrastructure is a key reason why medical professionals in poor countries are unproductive. This might in turn, as we argue in this paper, constitute a main mechanism underlying their emigration.

Against this background, the present paper investigates how two potential determinants, aid for health and local income levels, affect emigration rates of doctors and nurses from developing countries. By including nurses, we adopt a broader definition of medical brain drain than is found in most previous studies that were only concerned with the emigration of physicians. The ultimate objective is to obtain an indication of whether international efforts to improve local health infrastructure through foreign aid and to provide the right conditions for economic growth can actually help mitigate a potential medical brain drain in developing countries. ${ }^{1}$ Employing data on international flows of health personnel obtained from the OECD Health Workforce Migration dataset for the period 2000-2015, we estimate a gravity model of international migration.

Our contribution to the literature is threefold. Firstly, by considering aid and income effects jointly, we speak to two related strands of literature on the determinants of emigration, which have largely been treated separately in empirical research so far. On the one hand, several studies have analysed the effects of sector-specific aid so as to account for the heterogeneity of foreign assistance (Gamso \& Yuldashev, 2018a; Gamso \& Yuldashev, 2018b; Lanati \& Thiele, 2018a; Lanati \& Thiele, 2018b). A common conclusion of these studies is that aid can be effective in reducing aggregate migration if it is spent on the provision of public services. In a specific analysis for tertiary education, Lanati and Thiele (2020b) conclude that investing in the quality of tertiary education in recipient countries appears to be associated with lower outflows of students to donor countries. These findings are in accordance with the pioneering study by Dustmann and Okatenko (2014), which shows that contentment with various local amenities-including for instance healthcare, schools, air quality and the quality of a country's institutions-turns out to be a more important factor in shaping migration decisions than household wealth. We investigate whether the previous findings hold in the specific case of health personnel.

On the other hand, there is a strand of research that investigates the link between economic development and migration. By comparing the emigration rates of countries at different stages of economic development, an inverse u-shape emerges, giving rise to the notion of a 'migration hump' (e.g., Clemens, 2014; 
Hatton \& Williamson, 2002). Because the migration hump is typically estimated using cross-country data, it is best interpreted as capturing the long-term association between economic development and emigration. In contrast, recent studies that employ a panel data approach and thus tend to focus on short- to medium-term effects within countries have come up with opposing results. Clemens (2020), for example, finds that increasing GDP per capita is on average associated with more emigration in poor countries, and that the effect reverses only after GDP per capita exceeds about $\$ 10$ 000. In a similar vein, Bazzi (2017) shows that in Indonesia, positive agricultural income shocks lead to more labour emigration flows in poorer areas with a strong prevalence of small-scale agriculture, whereas such shocks lower emigration in the most developed rural areas. By contrast, Benček and Schneiderheinze (2020) and Clist and Restelli (2021) find that even at low initial levels of income, the relationship between economic growth and aggregate emigration is negative for a large sample of OECD destinations and for Italy specifically, even though the effects tend to be small. ${ }^{2}$ We add a disaggregated perspective to this literature by comparing the migration decisions of (relatively poor) nurses and (relatively rich) doctors. In our case, changes in GDP per capita can be regarded as a rough proxy for changes in health workers' wages, which would be the preferable indicator but is not available for the purpose of this analysis. A previous study by Bhargava and Docquier (2008) shows that physicians' wages in the country of origin are negatively related with physicians' emigration rate from developing countries.

Taken together, by considering the impact of aid for health and GDP per capita, we capture important monetary and non-monetary determinants of health workers' migration decisions.

Second, we shed light on the key mechanism through which aid for health is likely to affect the incentives of medical workers to emigrate from developing countries. Previous studies have consistently shown that aid specifically targeted at the health sector improves development indicators, such as infant mortality (e.g., Kotsadam et al., 2018; Mishra \& Newhouse, 2009). We are the first to test whether sector-specific foreign assistance leads to improvements in the quality of health infrastructure. This arguably has a more direct bearing on medical workers' migration decisions than health-related development outcomes as they affect their working conditions. Adovor et al. (2021) find that a higher number of physicians per thousand people are associated with less emigration by physicians. We use an instrumental variable (IV) approach based on a shiftshare instrument along the lines of Nunn and Qian (2014) to come closer to a causal interpretation of our estimates.

Third, most of the existing studies on the link between foreign assistance and emigration have focused on total migrant flows despite strong potential heterogeneity across sectors and skill levels, thus rendering any inference from aggregate data difficult. Exceptions include Lanati and Thiele (2020b), who investigate the impact of aid for education on international student mobility, and Moullan (2013), who considers the link between aid for health and physicians' emigration. Our investigation of health aid is closely related to Moullan (2013). We extend his work by taking the emigration of nurses into account. We also address various methodological concerns by employing the Pseudo-Poisson maximum likelihood (PPML) estimator with higher dimensional fixed effects, which represents the current state of the art in the estimation of gravity models.

We find that aid for health improves various components of local health infrastructure and has a negative effect on the emigration of both nurses and doctors. Higher income per capita is also associated with lower emigration from developing countries for doctors and nurses alike. Given that nurses typically belong to the poorer segments of populations in the countries of origin, the link appears to hold across income levels, corroborating what Bencek and Schneiderheinze (2020) as well as Clist and Restelli (2021) previously found at the aggregate level.

The remainder of the paper is structured as follows. In Section 2, we describe the data used in the empirical analysis and provide some descriptive evidence on the emigration patterns of the health workforce. Section 3 introduces our econometric approach. In section 4, we present the regression results. In doing so, we start with a baseline specification, add several robustness checks and finally deal with the mechanisms through which aid for health potentially affects the emigration of medical workers. Section 5 concludes. 


\section{DATA AND DESCRIPTIVE EVIDENCE}

Data on international flows of health personnel are taken from the OECD's Health Workforce Migration dataset. The dataset provides information on annual inflows into OECD countries over the period 2000-2015. ${ }^{3}$ These inflows are defined as (a) doctors who have obtained their first medical qualification (degree) in another country and are receiving new authorization in a given year to practice in the receiving country and (b) the number of nurses who have obtained a recognized qualification in nursing. The sources from which data are collected vary by destination. The preferred source is professional registers. Alternatively, data are also taken from working permits delivered to immigrants. ${ }^{4}$ The quality of the OECD's Health Workforce Migration dataset is high even though the coverage is not complete. A relatively large number of missing observations prevents us from performing a proper panel-data analysis. ${ }^{5}$ It is only for the United States, which is by far the main migrant destination for medical workers, that we have information on health workforce emigration for all the countries of origin over the whole period under consideration. We therefore present estimates based on a pooled gravity model for the whole set of available OECD destinations using a dataset which is representative of all South-North emigration of medical workers. In a robustness check, we estimate a panel-data model with the United States as the only migrant destination.

As shown in Figure 1, the United States is clearly ahead of all other OECD countries as the main destination for nurses ( $44 \%$ of foreign-born workers) as well as doctors ( $36 \%$ of foreign-born workers). Emigration patterns among countries of origin are fairly heterogeneous. In absolute terms, the Philippines is by far the leading emigration country for nurses with an average of over 8000 emigrants per year, followed by India with about $2700 .^{6}$ The largest number of doctors emigrates from India and Pakistan (2300 and 1150, respectively). When it comes to assessing the severity of the medical brain drain in a specific developing country, it is more relevant to look at the share of domestic medical workers that actually leave their home. The emigration rates of nurses are particularly high among Caribbean countries and in the Philippines, whereas several African countries exhibit high emigration rates among doctors.

Along the lines of Beine and Parsons (2015) as well as Bhargava and Docquier (2008), we define bilateral emigration rates as:

$$
E M_{i j t}^{h}=\frac{M_{i j t}^{h}}{\sum_{j} M_{i j t}^{h}+P_{i t}^{h}},
$$
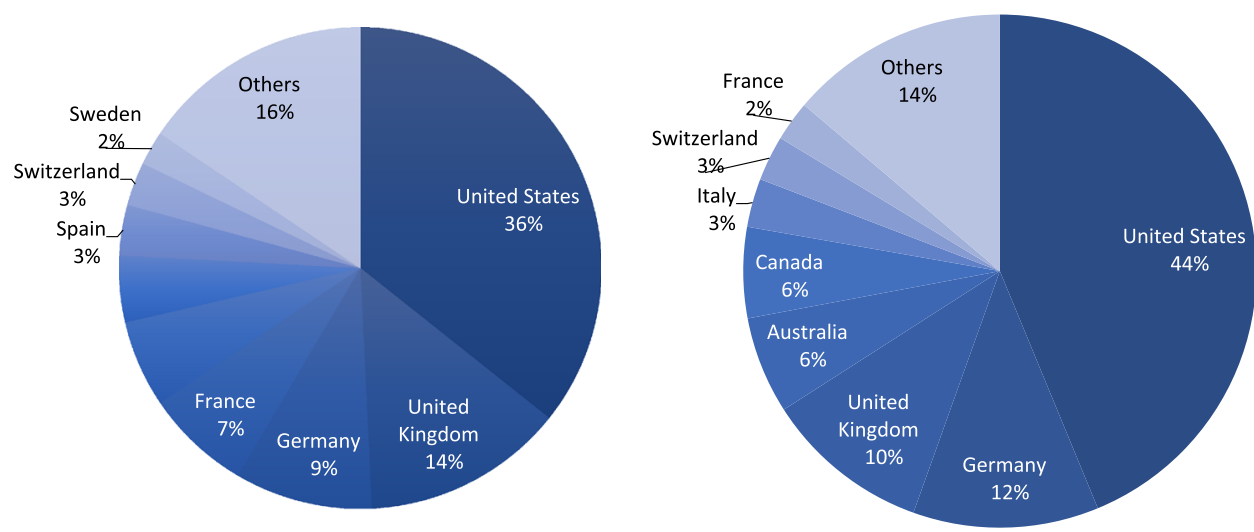

Source: DIOC 2010/11, LFS 2009/12. OECD International Migration Outlook 2015

FIGURE 1 Distribution of foreign-born doctors (left) and nurses (right) by country of residence in the OECD, 2010/11. Source: DIOC 2010/11, LFS 2009/12. OECD (2015) [Colour figure can be viewed at wileyonlinelibrary.com] 
where $M_{i j t}^{h}$ denotes the flow of healthcare workforce of type $h$ (nurses or doctors) from country $i$ to country $j$ at time $t$, while $P_{j} j t$ is the total healthcare workforce of type $h$ in the home country and $\sum_{j} M_{i j t}^{h}$ the sum of available emigrant flows from country i. ${ }^{7}$ In our baseline estimation, missing values for the population of doctors and nurses in the denominator are imputed using the average population density of the nurses and doctors multiplied by the recipient country's population. We perform a robustness check where missing values are imputed by allowing the number of nurses and doctors to vary proportionally to a country's total population.

For foreign assistance, our main explanatory variable under scrutiny alongside GDP per capita, we employ gross disbursements of Official Development Assistance (ODA) in the health sector expressed in constant US dollars from the OECD Creditor Reporting System (CRS) dataset that disaggregates aid items by sector. ${ }^{8}$ Following the methodology proposed by Qian (2015), we only use the transferred share of health ODA. This means that we subtract the portion of foreign assistance that is mostly spent within donor borders from total aid, including, for example, 'in-donor scholarships', 'administrative costs' and 'donor personnel'. The rationale behind this is that only those resources that are actually transferred to recipient countries have the potential to affect migration decisions (Lanati \& Thiele, 2020a). In order to smooth the volatility in the annual provision of aid disbursements, we use 4-year averages of the aid received. ${ }^{9}$ GDP per capita is expressed in purchasing power parities (PPPs) with constant US\$ (2011 prices). Table A4 in the appendix lists the sources and provides a brief description of these variables and other covariates that were used as controls in the empirical analysis, and Table A5 shows the summary statistics.

\section{3 | ECONOMETRIC APPROACH}

Our empirical analysis relies on a standard gravity model of international migration (e.g., Beine \& Parsons, 2015), in which bilateral emigration rates of healthcare workers from country of origin $i$ to country of destination $j$ are related to dyadic $O D_{i j t}-1$ as well as origin-specific determinants $O_{i t}-1$. $O_{i t}-1$ includes our variables of interest, namely, GDP per capita and the total transferred health aid per capita received by country $i$. The estimation equation reduces to

$$
\ln \left(E M_{i j t}\right)=\alpha_{i j}+\alpha_{j t}+\ln \left(O_{i t-1}\right) * \Delta+\ln \left(O D_{i j t-1}\right) * \vartheta+e_{i j t}
$$

In addition to the two main variables of interest, we include a standard set of time-varying covariates. These comprise origin-specific factors such as a dummy variable that captures the presence of conflicts; the number of natural disasters in a given year; and a proxy for the quality of governance and local institutions obtained with a principal component analysis (PCA) of the six World Bank Governance Indicators along the lines of Ariu et al. (2016). As a dyadic determinant, we capture time-varying migrant network effects through the inclusion of the lagged bilateral migrant stocks from country $i$ living in country $j$.

To account for cross-country heterogeneity and attenuate potential estimation biases, the econometric specification includes destination-year $\left(\alpha_{j} t\right)$ and asymmetric dyadic $\left(\alpha_{i}\right)$ fixed effects. Although origin-time dummies would fully absorb multilateral resistance to migration (Beine et al., 2015), ${ }^{10}$ they cannot be added in our setting as they would completely absorb the effect of our variable of interest. Including destination-year fixed effects, however, fully captures multilateral resistance to migration in countries of destination. This can be assumed to be the dominant factor in the context of international migration, where destination-specific immigration policies play a central role (Beine \& Parsons, 2015). In addition, asymmetric dyadic fixed effects address the bias that might result from the omission of unobserved variables and restore the cross-sectional independence of the error terms (Faye \& Niehaus, 2012; Bertoli \& Moraga, 2015). For instance, bilateral cultural or political affinity-which is unlikely to exhibit strong movements over short periods of time and is often very hard to measure empirically-is plausibly associated with both international mobility and foreign aid flows. 
All covariates are predetermined-lagged one period-with respect to the emigration of medical workers. This to some extent addresses concerns that our variables of interest may be endogenous due to reverse causality. In addition, regarding the foreign aid variable, only the bilateral part of the total amounts allocated to country $i$ possibly responds to migration from country $i$ to country $j$. This may be due to the fact that migrants successfully lobby the destination countries' governments to increase disbursements to their home countries (Lahiri \& Raimondos-Møller, 2000; Lanati \& Thiele, 2018a). Hence, we argue that reverse causality should not severely affect our results, at least as far as foreign aid is concerned. In any case, given that a minor role played by simultaneity bias cannot be ruled out, we still desist to make strong causal claims. The standard procedure to tackle the issue of reverse causality is to employ an IV strategy: in our gravity setting, however, we would have to come up with an IV with an ijt dimension, while our variables of interest are origin specific. We are not aware of an instrument that is suitable in such a setting.

A further potential methodological concern relates to the consistency of the standard errors. The error term in the gravity specification might be correlated within dimensions of the panel, leading to inconsistent estimates of Equation $1 .^{11}$ To address this issue, we follow the approach implemented by Cameron et al. (2011) as well as Faye and Niehaus (2012) and include non-nested multiway clusterings of standard errors along all three dimensions of the panel, that is 'donors', 'recipients' and 'years'.

Following previous analyses based on gravity models (e.g., Bertoli \& Moraga, 2015; Beine \& Parsons, 2015; Lanati \& Thiele, 2018a), we apply the PPML approach when estimating Equation 1. The rationale for doing so is that our sample contains a fairly high share of zeros-around $23 \%$ and $17 \%$ of total observations for nurses and doctors, respectively. As Silva and Tenreyro (2006) have shown, a significant share of zero observations creates a correlation between the covariates and the error term, rendering ordinary least squares (OLS) estimates inconsistent.

\section{4 | RESULTS}

Equation 1 is estimated separately for nurses and doctors. The results are presented in Tables 1 and 2 , respectively. ${ }^{12}$ We first show estimates of the isolated effect of health aid and per capita income without any further controls (Columns 1 and 2). We only include the set of fixed effects in line with Beine and Parsons (2017) and Cattaneo and Peri (2016). Although this specification is potentially subject to model misspecification, its advantage is that it does not include any covariate that could absorb part of the overall effect of the variables of interest. We then consider health aid and income per capita jointly in the same specification (Column 3) and finally add several controls (Columns 4 and 5) to check whether our core results survive their inclusion. The results suggest that the time variation of both per capita income and health aid is negatively associated with bilateral emigration of the healthcare workforce. In substantive terms, the effect of per-capita health aid is very close to previous estimates based on gravity models for international migration (e.g., Lanati \& Thiele, 2018a) and is similar across the two healthcare workforce categories. According to our point estimates, doubling the volume of transferred foreign assistance received by developing countries in the health sector would lower the healthcare workforce's emigration rates by around $10 \%$.

Both coefficients of interest are very similar across specifications. As shown in Columns 3-5, the effect of health aid and per capita income maintain roughly the same magnitude when included together in the same regression. This suggests that the impacts of health aid and per capita income are not collinear and that in fact they influence healthcare workers' migration decisions through separate and distinct channels. More specifically, the provision of health aid is most likely to affect non-monetary dimensions of well-being in developing countries including the quality and supply of healthcare infrastructure and services. A rise in GDP per capita, on the other hand, proxies for higher wages and better income opportunities in recipient countries. Although there appears to be some consensus on the role of improved public services in reducing emigration from developing countries (Dustmann \& Okatenko, 2014), the impact of a rise in income on emigration decisions is subject to contrasting 
TAB LE 1 Impact of per capita transferred health aid on migration of nurses (bilateral rates): 2006-2015

\begin{tabular}{|c|c|c|c|c|c|}
\hline $\begin{array}{l}\text { Estimator } \\
\text { Dep. variable } \\
\text { Sample destinations }\end{array}$ & $\begin{array}{l}\text { (1) } \\
\text { PPML } \\
\text { Migration rate } \\
\text { Whole }\end{array}$ & $\begin{array}{l}\text { (2) } \\
\text { PPML } \\
\text { Migration rate } \\
\text { Whole }\end{array}$ & $\begin{array}{l}\text { (3) } \\
\text { PPML } \\
\text { Migration rate } \\
\text { Whole }\end{array}$ & $\begin{array}{l}\text { (4) } \\
\text { PPML } \\
\text { Migration rate } \\
\text { Whole }\end{array}$ & $\begin{array}{l}\text { (5) } \\
\text { PPML } \\
\text { Migration rate } \\
\text { Whole }\end{array}$ \\
\hline Log health ODA pc (o) & $\begin{array}{l}-0.131^{*} \\
(-2.06)\end{array}$ & & $\begin{array}{l}-0.100^{*} \\
(-2.29)\end{array}$ & $\begin{array}{c}-0.100 \\
(-1.93)\end{array}$ & $\begin{array}{l}-0.101^{*} \\
(-2.23)\end{array}$ \\
\hline Log GDP pc const. \$ PPP (o) & & $\begin{array}{l}-2.462^{* * *} \\
(-6.29)\end{array}$ & $\begin{array}{r}-2.277^{* * *} \\
(-7.53)\end{array}$ & $\begin{array}{l}-2.276^{* * *} \\
(-6.45)\end{array}$ & $\begin{array}{l}-2.412^{* * *} \\
(-7.04)\end{array}$ \\
\hline Log diaspora (o to d) & & & & $\begin{array}{l}-0.00627 \\
(-0.05)\end{array}$ & $\begin{array}{l}-0.0224 \\
(-0.34)\end{array}$ \\
\hline Quality of institutions (o) & & & & & $0.116(1.45)$ \\
\hline Conflict (o) & & & & & $\begin{array}{l}-0.196 \\
(-0.47)\end{array}$ \\
\hline Natural disasters (o) & & & & & $\begin{array}{l}0.0199^{* * *} \\
(7.83)\end{array}$ \\
\hline$N$ & 2541 & 2541 & 2541 & 2541 & 2541 \\
\hline Destination-year FE & $x$ & $x$ & $x$ & $x$ & $x$ \\
\hline Origin-destination FE & $\mathrm{x}$ & $x$ & $x$ & $x$ & $\mathrm{x}$ \\
\hline Destinations & 18 & 18 & 18 & 18 & 18 \\
\hline Origins & 108 & 108 & 108 & 108 & 108 \\
\hline$\%$ Zeros & $23.6 \%$ & $23.6 \%$ & $23.6 \%$ & $23.6 \%$ & $23.6 \%$ \\
\hline
\end{tabular}

Note: $z$ statistics are in parentheses. Robust standard errors in parentheses in Columns 1-5 are multiway clustered by donor, recipient and year. Columns 1-5 show the estimates using the enlarged sample that includes all destinations for the years 20062015. All origin specific variables are lagged at $t$-1. For foreign aid, we take the 4 -year average. So total transferred ODA received at time $t$ is the 4-year average between $t-1$ and $t-4$. Emigration rates are calculated using interpolated values of nurses population, and the missing values of doctors population are imputed using the average of the nurses population ratio multiplied by country's total population. The OECD destination countries included in the sample are the following: Belgium, Canada, Denmark, Germany, Greece, Hungary, Ireland, Israel, Italy, Latvia, Netherlands, New Zealand, Norway, Poland, Switzerland, Turkey, the United Kingdom and the United States.

Abbreviations: FE, fixed effect; ODA, Official Development Assistance; PPP, purchasing power parity; PPML, Pseudo-Poisson maximum likelihood.

${ }^{*} p<0.05 .{ }^{* *} p<0.01 .{ }^{* * *} p<0.001$.

forces. It not only provides an incentive to stay by narrowing the income gap, but it also makes it easier to incur the cost of emigration, with no clear prediction regarding its net effect. According to the migration hump hypothesis (e.g., Clemens, 2014; Hatton \& Williamson, 2002), the effect is non-linear: At low levels of per capita GDP, additional income makes it easier for would-be migrants in countries of origin to incur migration costs, thus raising the number of people who leave. At higher development levels, incentives to stay eventually become more important than budgetary considerations. The migration hump hypothesis receives empirical support in cross-sectional settings, which involves the comparison of emigration rates from richer and poorer developing countries (e.g., Clemens, 2014), while evidence is mixed so far with panel data. Our results corroborate the previous findings obtained by Benček and Schneiderheinze (2020) and Clist and Restelli (2021) that there is a negative but quantitatively moderate impact of per capita GDP on emigration regardless of sending countries' level of income once cross-country heterogeneity is accounted for.

When looking at the two groups of medical workers, the estimated negative relationship between GDP per capita growth and the emigration of doctors, which corroborates previous findings by Adovor et al. (2021) and Moullan (2013), could still be in accordance with the migration hump hypothesis as doctors may lie on the 
TAB LE 2 Impact of per capita Transferred Health Aid on Migration of Doctors (Bilateral Rates) 2006-2015

\begin{tabular}{|c|c|c|c|c|c|}
\hline $\begin{array}{l}\text { Estimator } \\
\text { Dep. variable } \\
\text { Sample destinations }\end{array}$ & $\begin{array}{l}\text { (1) } \\
\text { PPML } \\
\text { Migration rate } \\
\text { Whole }\end{array}$ & $\begin{array}{l}\text { (2) } \\
\text { PPML } \\
\text { Migration rate } \\
\text { Whole }\end{array}$ & $\begin{array}{l}\text { (3) } \\
\text { PPML } \\
\text { Migration rate } \\
\text { Whole }\end{array}$ & $\begin{array}{l}\text { (4) } \\
\text { PPML } \\
\text { Migration rate } \\
\text { Whole }\end{array}$ & $\begin{array}{l}\text { (5) } \\
\text { PPML } \\
\text { Migration rate } \\
\text { Whole }\end{array}$ \\
\hline Log health ODA pc (o) & $\begin{array}{l}-0.100^{* *} \\
(-2.62)\end{array}$ & & $\begin{array}{l}-0.0964^{* *} \\
(-2.63)\end{array}$ & $\begin{array}{l}-0.0936^{*} \\
(-2.16)\end{array}$ & $\begin{array}{l}-0.0927^{*} \\
(-2.07)\end{array}$ \\
\hline Log GDP const. \$ PPP (o) & & $\begin{array}{l}-0.636^{*} \\
(-2.04)\end{array}$ & $\begin{array}{l}-0.605^{*} \\
(-2.14)\end{array}$ & $\begin{array}{c}-0.568 \\
(-1.86)\end{array}$ & $\begin{array}{c}-0.630^{*} \\
(-2.37)\end{array}$ \\
\hline Log diaspora (o to d) & & & & $\begin{array}{c}-0.116 \\
(-1.69)\end{array}$ & $\begin{array}{c}-0.118 \\
(-1.71)\end{array}$ \\
\hline Quality of institutions (o) & & & & & $0.0419(0.37)$ \\
\hline Conflict (o) & & & & & $\begin{array}{l}-0.0450 \\
(-0.64)\end{array}$ \\
\hline Natural disasters (o) & & & & & $\begin{array}{l}-0.00761 \\
(-0.59)\end{array}$ \\
\hline$N$ & 4387 & 4387 & 4387 & 4387 & 4387 \\
\hline Destination-year FE & $x$ & $x$ & $x$ & $x$ & $x$ \\
\hline Origin-destination FE & $x$ & $x$ & $x$ & $x$ & $x$ \\
\hline Destinations & 23 & 23 & 23 & 23 & 23 \\
\hline Origins & 107 & 107 & 107 & 107 & 107 \\
\hline$\%$ Zeros & $16.7 \%$ & $16.7 \%$ & $16.7 \%$ & $16.7 \%$ & $16.7 \%$ \\
\hline
\end{tabular}

Note: Robust standard errors in parentheses in Columns 1-5 are multiway clustered by donor, recipient and year. $z$ statistics are in parentheses. The following small countries of origin-Antigua and Barbuda, Belize, Dominica, Grenada, Saint Kitts and Nevis, Saint Lucia and Saint Vincent and the Grenadines-are excluded from the sample. Columns 1-5 show the correspondent estimates using the enlarged sample that includes all destinations for the years 2006-2015. All origin specific variables are lagged at $t-1$. For foreign aid, we take the 4-year average. So total transferred ODA received at time $t$ is the 4 -year average between $t-1$ and $t$ - 4 . Emigration rates are calculated using interpolated values of doctors population at the denominator, and missing values of doctors population are imputed using the average of the doctors population ratio multiplied by country's total population. The OECD destination countries included in the sample are the following - Belgium, Canada, Chile, Czech Republic, Denmark, Estonia, Finland, France, Greece, Hungary, Ireland, Israel, Latvia, Lithuania, Netherlands, New Zealand, Norway, Slovenia, Sweden, Switzerland, Turkey, the United Kingdom and the United States.

Abbreviations: FE, fixed effect; ODA, Official Development Assistance; PPP, purchasing power parity; PPML, Pseudo-Poisson maximum likelihood.

${ }^{*} p<0.05 .{ }^{* *} p<0.01 .{ }^{* * *} p<0.001$.

downward-sloping segment of the curve. ${ }^{13}$ However, when we extend the analysis to nurses who are poorer than doctors and more likely to be located on the upward-sloping part of the hump, there is an even stronger negative relationship. Hence, even for nurses, migration decisions are on balance more strongly affected by the incentive effects of higher incomes (i.e., a greater incentive to stay) than by the loosening of budgetary constraints (and the consequent greater financial ability to emigrate).

The fact that cross-sectional and time-series estimates of the development-migration nexus may point in different directions is illustrated in Table 3, where regression results are reported based on Equation 1, but without including dyadic fixed effects that account for cross-country heterogeneity. Omitting country-pair fixed effects reverses the sign of the relationship between development and emigration of nurses (Columns 1 and 2) and leads to a positive and significant relationship between health aid and the emigration of doctors from developing countries (Columns 3 and 4). ${ }^{14}$

This finding is in line with previous research. As shown, for instance, by Benček and Schneiderheinze (2020) and Ortega and Peri (2013) in their analysis of the relationship between income and emigration rates, there tend to be large differences between panel and cross-sectional estimates. Their findings show that a pure cross-sectional 
TABLE 3 Not accounting for cross-country heterogeneity at the origin

\begin{tabular}{|c|c|c|c|c|}
\hline \multirow{3}{*}{ Estimator } & (1) & (2) & (3) & (4) \\
\hline & PPML & PPML & PPML & PPML \\
\hline & Migration & Migration & Migration & Migration \\
\hline Dep. variable & rate nurses & rate nurses & rate doctors & rate doctors \\
\hline Sample destinations & Whole & Whole & Whole & Whole \\
\hline \multirow[t]{2}{*}{ Log health ODA pc (o) } & 0.113 & 0.107 & $0.325^{* * *}$ & $0.323^{* * *}$ \\
\hline & $(0.85)$ & $(0.82)$ & (3.74) & (3.69) \\
\hline \multirow[t]{2}{*}{ Log GDP const. \$ PPP (o) } & 0.0650 & 0.0548 & -0.0173 & -0.0133 \\
\hline & $(0.58)$ & $(0.50)$ & $(-0.10)$ & $(-0.08)$ \\
\hline$N$ & 2,541 & 2,541 & 4,387 & 4,387 \\
\hline \multicolumn{2}{|l|}{ Destination-year FE } & $x$ & & $x$ \\
\hline Destination FE & $x$ & & $x$ & \\
\hline Year FE & $x$ & & $x$ & \\
\hline Destinations & 18 & 18 & 23 & 23 \\
\hline Origins & 108 & 108 & 107 & 107 \\
\hline$\%$ Zeros & $23.6 \%$ & $23.6 \%$ & $16.7 \%$ & $16.7 \%$ \\
\hline
\end{tabular}

Note: $z$ statistics are in parentheses. Robust standard errors in parentheses are multiway clustered by donor, recipient and year. Abbreviations: FE, fixed effect; ODA, Official Development Assistance; PPP, purchasing power parity; PPML, Pseudo-Poisson maximum likelihood.

${ }^{*} p<0.05 .^{* *} p<0.01 .{ }^{* * *} p<0.001$.

exercise leads to a positive relationship; by contrast, when exploiting the variation over time and accounting for heterogeneity across countries of origin and destination through an appropriate set of fixed effects, they consistently find a negative association between income and emigration. This result is independent of the level of income a country starts out at.

\section{1 $\quad$ Robustness}

The negative relationship between development and the emigration of healthcare workforce that emerges from our benchmark estimates presented in Tables 1 and 2 could in principle be driven by a small subset of relatively rich recipient countries. To address this issue, we progressively drop recipient countries with the highest GDP per capita by yearly income quintile (Table 4). The results suggest that income per capita is negatively related to the emigration of healthcare workforce across different income categories. Interestingly, as we progressively omit the richest countries from the sample, the provision of foreign aid becomes relatively more important for the emigration decisions of nurses at the expense of GDP per capita. In other words, in poorer contexts, the quality and supply of healthcare services and infrastructures induced by foreign aid matter relatively more for migration decisions than monetary dimensions of well-being. The opposite applies for doctors whose decision on whether to emigrate or not is relatively more sensitive to the level of income in more deprived areas.

The pattern for GDP per capita shown in Table 4 might be explained by the fact that financial constraints are more binding for nurses as compared with doctors. For doctors, the falling impact with rising incomes would then simply indicate lower incentives to emigrate as the income gap between origin and destination narrows. For nurses, the negative incentive effect of rising incomes would partly be offset by a loosening of budget constraints which are most binding in low-income settings. A larger provision of health aid-if not wasted-can be expected to improve the supply and the quality of local healthcare infrastructures in developing countries (see below). As Dustmann and Okatenko (2014) pointed out, the quality of local amenities and public services-including healthcare 


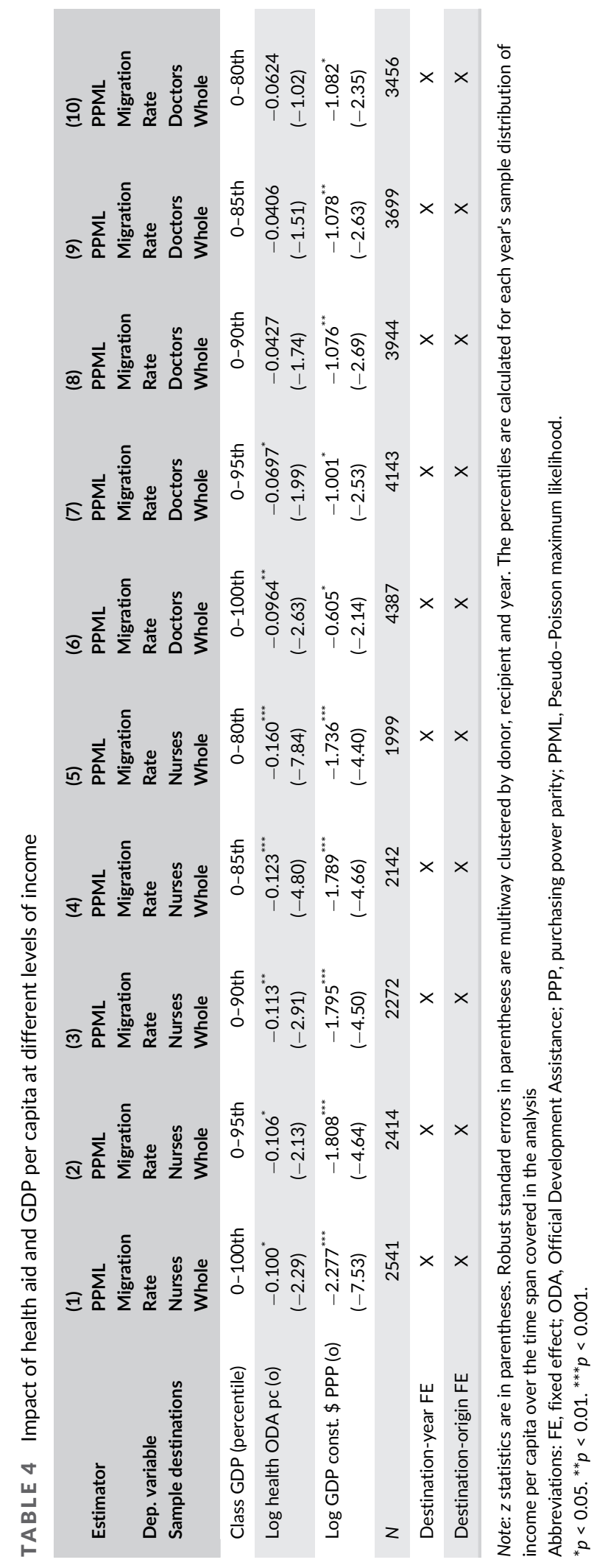


infrastructures-is an important determinant of emigration decisions, especially from poor and deprived areas whose healthcare system suffers from insufficient financial and human resources as well as limited institutional capacity and infrastructure. Against this background, our finding that the aid effect on nurses' emigration lowers with higher levels of per capita income might indicate that the marginal productivity of one dollar of foreign aid spent in the healthcare system decreases with better quality/larger supply of healthcare infrastructure. The reverse pattern for doctors might indicate that they benefit relatively less from the international support typically forthcoming in low-income settings-for instance the improvement of rural health posts or the provision of basic equipment such as syringesand relatively more from the health aid provided in higher income settings, which also tends to include more sophisticated equipment that improves the conditions for doctors working in hospitals.

Despite the large set of fixed effects which attenuate omitted variable bias and the pre-determined (lagged) covariates with respect to emigration rates that mitigate potential biases deriving from reverse causality, our specification might still suffer from endogeneity. First, we address reverse causality and, at same time, test for the timing of aid and income effects by introducing longer time lags. ${ }^{15}$ The results shown in Table 5 suggest that both the negative effects of health aid and income per capita remain statistically significant and become larger when passing from the very short to the short-to-medium term. The result for foreign aid is in accordance with Dreher et al. (2019) and indicates that it takes time for aid projects to have an impact on wellbeing and thus to influence emigration rates. As for per capita GDP, we interpret this finding as the 'natural' lagged effect of emigration decisions in response to income variations: migration decisions are not taken overnight and require some planning ahead of settling into a new country.

Second, there might be time-varying dyadic-specific omitted variables that could be correlated with the error term and thus could bias our parameters of interest. For instance, the allocation of ODA is in large part affected by donors' strategic motivations (see Alesina \& Dollar, 2000), such as bilateral economic and political alignments, which can plausibly have an effect on emigration rates (see Campaniello, 2014). We address this issue by including bilateral trade flows (exports) and an affinity index of the UN General Assembly voting created by Voeten et al. (2009) as additional control variables in the econometric specifications. ${ }^{16}$ The estimates are reported in Table 6. The newly added controls do not significantly influence the emigration of health personnel. Their insignificance points to the absence of network effects through trade and political relations. ${ }^{17}$ This corroborates the finding reported in Tables 1 and 2 that diaspora networks do not appear to play a role in determining the emigration pattern of doctors and

TAB LE 5 Addressing endogeneity: Past values of aid and income per capita

\begin{tabular}{|c|c|c|c|c|c|c|}
\hline & (1) & (2) & (3) & (4) & (5) & (6) \\
\hline Estimator & PPML & PPML & PPML & PPML & PPML & PPML \\
\hline Lag & 1 year & 2 year & 3 year & 1 year & 2 year & 3 year \\
\hline Dep. variable & $\begin{array}{l}\text { Migration } \\
\text { rate whole }\end{array}$ & $\begin{array}{l}\text { Migration } \\
\text { rate whole }\end{array}$ & $\begin{array}{l}\text { Migration } \\
\text { rate whole }\end{array}$ & $\begin{array}{l}\text { Migration } \\
\text { rate whole }\end{array}$ & $\begin{array}{l}\text { Migration } \\
\text { rate whole }\end{array}$ & $\begin{array}{l}\text { Migration rate } \\
\text { whole }\end{array}$ \\
\hline Sample destinations & Nurses & Nurses & Nurses & Doctors & Doctors & Doctors \\
\hline Log health ODA pc (o) & $\begin{array}{l}-0.112^{*} \\
(-2.34)\end{array}$ & $\begin{array}{l}-0.172^{* *} \\
(-2.86)\end{array}$ & $\begin{array}{l}-0.330^{*} \\
(-2.50)\end{array}$ & $\begin{array}{l}-0.0966^{* *} \\
(-2.64)\end{array}$ & $\begin{array}{l}-0.124^{*} \\
(-2.18)\end{array}$ & $\begin{array}{l}-0.127^{*} \\
(-2.23)\end{array}$ \\
\hline Log GDP const. \$ PPP (o) & $\begin{array}{l}-2.288^{* * *} \\
(-7.66)\end{array}$ & $\begin{array}{c}-3.130^{* * *} \\
(-49.31)\end{array}$ & $\begin{array}{l}-4.065^{* * *} \\
(-6.16)\end{array}$ & $\begin{array}{l}-0.616^{*} \\
(-2.15)\end{array}$ & $\begin{array}{l}-0.704^{* *} \\
(-2.69)\end{array}$ & $\begin{array}{l}-0.802^{* *} \\
(-2.91)\end{array}$ \\
\hline$N$ & 2,580 & 2,230 & 1921 & 4,441 & 4,000 & 3,620 \\
\hline Destination-year FE & $x$ & $x$ & $x$ & $x$ & $x$ & $x$ \\
\hline Origin-destination FE & $x$ & $x$ & $x$ & $x$ & $x$ & $x$ \\
\hline
\end{tabular}

Note: $z$ statistics are in parentheses. Robust standard errors in parentheses are multiway clustered by donor, recipient and year. The regressions do not include controls other than our two variables of interest.

Abbreviations: FE, fixed effect; ODA, Official Development Assistance; PPP, purchasing power parity; PPML, Pseudo-Poisson maximum likelihood.

${ }^{*} p<0.05 .{ }^{* *} p<0.01{ }^{* * *} p<0.001$. 
TABLE 6 Addressing endogeneity: Augmented gravity model

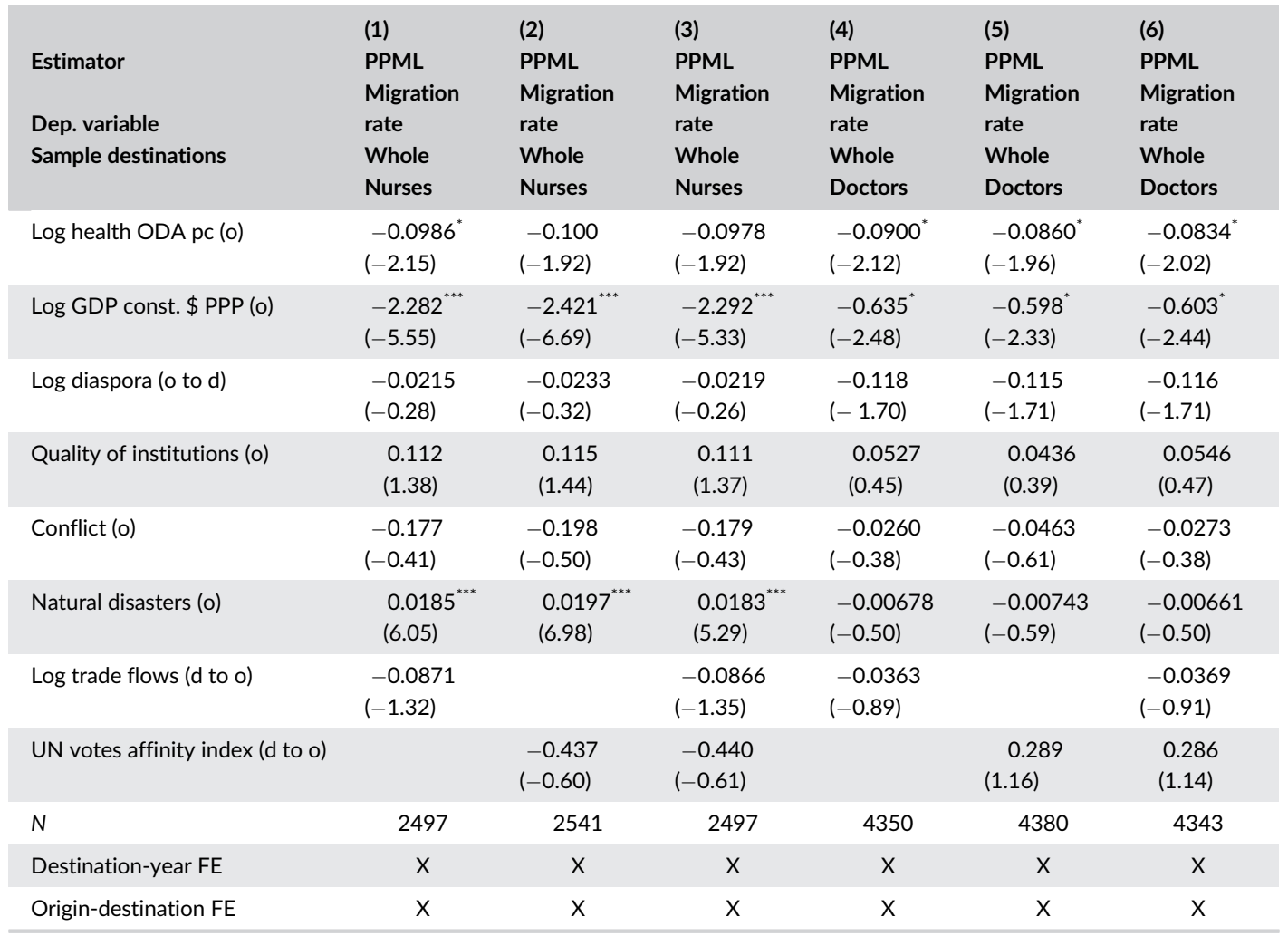

Note: $z$ statistics are in parentheses. Robust standard errors in parentheses in Columns 1-5 are multiway clustered by donor, recipient and year. The regressions include log trade flows ( $\mathrm{d}$ to o) and UN Votes Affinity Index ( $\mathrm{d}$ to o on top of the covariates included in the model estimated in Column 5 of Tables 1 and 2. All regressors are lagged at $t-1$.

Abbreviations: FE, fixed effect; ODA, Official Development Assistance; PPP, purchasing power parity; PPML, Pseudo-Poisson maximum likelihood.

${ }^{*} p<0.05 .{ }^{* *} p<0.01 .{ }^{* * *} p<0.001$.

nurses over and above what is captured by the full set of fixed effects. ${ }^{18}$ Importantly, both income per capita and health aid effects are largely unaffected; that is, our key results are robust to the inclusion of political affinity scores in the UN assembly and export variables.

Finally, we investigate whether our baseline results based on a pooled gravity model with multiple destinations hold when we estimate a panel-data model, with the United States as the only migrant destination. This econometric exercise automatically rules out any potential inconsistencies in the measurement of healthcare workforce emigration flows across destinations. As shown in Table 7, the findings are qualitatively similar to the benchmark estimates despite a considerable loss of statistical power due to the lower number of observations. More specifically, all the parameters of interest have the expected sign and the effects are statistically significant with the exception of income per capita for doctors' emigration.

\section{2 | Potential mechanisms}

The empirical analysis presented in the previous subsection suggests that a rise in foreign assistance in the health sector leads to lower emigration among medical workers from developing countries. Our hypothesis is that foreign 
TAB LE 7 Panel setting: The United States as the only destination

\begin{tabular}{|c|c|c|}
\hline & (1) & (2) \\
\hline & Nurses & Doctors \\
\hline Estimator & PPML & PPML \\
\hline Dep. variable & Migration rate & Migration rate \\
\hline Sample destinations & Whole & Whole \\
\hline Log health ODA pc (o) & $-0.155^{*}(-2.18)$ & $-0.158(-1.81)$ \\
\hline Log GDP pc const. \$ PPP (o) & $-2.265(-1.88)$ & $-0.237(-0.34)$ \\
\hline$N$ & 973 & 937 \\
\hline Year FE & $x$ & $x$ \\
\hline Origin FE & $x$ & $x$ \\
\hline Destinations & 1 & 1 \\
\hline Origins & 102 & 96 \\
\hline$\%$ Zeros & $35.2 \%$ & $20.8 \%$ \\
\hline
\end{tabular}

Note: $z$ statistics are in parentheses. Robust standard errors are multiclustered by recipient and year.

Abbreviations: FE, fixed effect; ODA, Official Development Assistance; PPP, purchasing power parity; PPML, PseudoPoisson maximum likelihood.

${ }^{*} p<0.05 .{ }^{* *} p<0.01 .{ }^{* * *} p<0.001$.

assistance influences doctors and nurses' emigration decisions through the improvements to local amenities, in particular regarding health infrastructure. To test this hypothesis, we use proxies of the quality of health infrastructure such as the number of doctors, nurses and hospital beds per capita as well as the percentage of immunized children. The latter can be regarded as a quality indicator for primary healthcare. All of these variables arguably cover relevant dimensions of working conditions for health personnel.

We first run OLS regressions with country and year fixed effects, in which we focus on the relationship between the time variation of per capita health aid and the quality of healthcare infrastructure in the recipient country. In contrast to the baseline regressions above, we now depart from the standard dyadic gravity framework and can use time-varying and country-specific IVs. Hence, in a second step, we instrument foreign assistance in the health sector with a shift-share instrument along the lines of Nunn and Qian (2014) as well as Dreher and Langlotz (2020). Specifically, we first construct a time-invariant variable which is the probability of each recipient country $i$ to receive aid from a particular donor $j$ in the period for which data are available (2002-2018). Following Dreher et al. (2019), the probability of receiving aid from donor $j$ is defined as $\overline{p_{j, i}}=\frac{1}{11} \sum_{t=1}^{11} p_{j, i, t} . p_{j}, i, t$ denotes a binary indicator that is equal to one if recipient $i$ receives foreign assistance in the health sector from donor $j$ at time $t$. We then multiply this term by donor-government fractionalization, $F R A C_{j t}$, and aggregate over all donors, that is, $\sum_{j} F R A C_{j t} * \overline{p_{j, j}}$. The instrument varies across recipients $i$ and years $t$. As concerns the relation of the instrument with the volume of aid received, Dreher and Langlotz (2020, p. 1172) argue that "higher fractionalization increases donor-government expenditures, which in turn increases the total amount of aid given by a donor. Countries that receive more aid from a given donor have a higher probability of receiving a larger share of increases in aid compared to countries that hardly receive any aid from the donor". We test the strength of the IV using the standard F statistics for weak instruments. In contrast, it is not possible to test for the exogeneity of the instrument through the Hansen $J$ test given that the model is exactly identified. Yet, our identifying assumption is unlikely to be violated. It requires that the quality of health infrastructure in "countries with differing probabilities of receiving aid will not be affected differently by changes in donor-government fractionalization, other than via the impact of health aid, when controlling for country and year fixed effects" (Dreher \& Langlotz (2020, p. 1173). The first stage Kleibergen-Paap F statistic for the excluded instrument is above 10 in all the specifications, which is in line with previous research using this kind of IV (e.g., Nunn \& Qian, 2014). ${ }^{19}$ 
The results are reported in Table 8. According to the IV estimates, a rise in health aid enhances the percentages of vaccinated children and improves the share of healthcare workers in the populations of recipient countries. ${ }^{20}$ We corroborate these findings with some cross-sectional evidence, where we exploit various measures of health infrastructure from the WHO for which there is not enough variation over time. The estimates shown in Table 9 indicate that countries that receive relatively higher levels of health aid per capita display better indicators of healthcare infrastructure such as a higher number of health posts, health centres, etc. Overall, there is evidence supporting our hypothesis that aid for health leads to better working conditions for health personnel in developing countries.

Whether better working conditions in health facilities do indeed provide an incentive for health workers to stay in their home countries is not well established in the literature. For the case of physicians' emigration, Adovor

\section{TABLE 8 Mechanisms: Aid effectiveness}

\begin{tabular}{|c|c|c|}
\hline $\begin{array}{l}\text { Estimator } \\
\text { Model }\end{array}$ & $\begin{array}{l}\text { (1) } \\
\text { OLS }\end{array}$ & $\begin{array}{l}(2) \\
2 S L S\end{array}$ \\
\hline \multicolumn{3}{|l|}{ Dep. variable: } \\
\hline \multicolumn{3}{|l|}{ Doctors (per 10000 people) } \\
\hline Log health ODA pc (o) & $0.00687(0.59)$ & $0.277(1.97)$ \\
\hline$N$ & 1,382 & 1,382 \\
\hline Kleibergen-Paap F statistic & & 13.933 \\
\hline \multicolumn{3}{|l|}{ Dep. variable: } \\
\hline \multicolumn{3}{|l|}{ Nurses (per 10000 people) } \\
\hline Log health ODA pc (o) & $0.0204(0.93)$ & $0.296(1.78)$ \\
\hline$N$ & 1,413 & 1,413 \\
\hline Kleibergen-Paap F statistic & & 13.901 \\
\hline \multicolumn{3}{|l|}{ Dep. variable: } \\
\hline \multicolumn{3}{|c|}{ Immunization, DPT (\% of children ages $12-23$ months) } \\
\hline Log health ODA pc (o) & $0.0132(2.02)$ & $0.170^{*}(2.42)$ \\
\hline$N$ & 1711 & 1711 \\
\hline Kleibergen-Paap F statistic & & 10.936 \\
\hline \multicolumn{3}{|l|}{ Dep. variable: } \\
\hline \multicolumn{3}{|c|}{ Immunization, measles (\% of children ages $12-23$ months) } \\
\hline Log health ODA pc (o) & $0.0181^{*}(2.51)$ & $0.151^{*}(2.46)$ \\
\hline$N$ & 1711 & 1711 \\
\hline Kleibergen-Paap F statistic & & 10.936 \\
\hline \multicolumn{3}{|l|}{ Dep. variable: } \\
\hline \multicolumn{3}{|c|}{ Hospital beds (per 10000 people) } \\
\hline Log health ODA pc (o) & $0.00517(0.26)$ & $0.184(0.89)$ \\
\hline$N$ & 1692 & 1692 \\
\hline Kleibergen-Paap F statistic & & 10.439 \\
\hline
\end{tabular}

Note: $z$ statistics are in parentheses. Robust standard errors in parentheses are multiway clustered by recipient and year. The regressions include a dummy for the presence of conflicts, along with country and year fixed effects, and cover the period 2004-2016. ODA variable is lagged one year and is the average over four-year periods ( $t-1, t-4)$; for the years 2005 and 2004 , ODA is the average over 3- $(t-1$ to $t-3)$ and 2 -year periods ( $t-1$ and $t-2)$, respectively. Iran and North Korea are excluded from the sample because they exhibit values of health infrastructures incredibly high with respect to the sample average and whose reliability may not be completely accurate.

Abbreviations: 2SLS, two-stage least squares; ODA, Official Development Assistance; OLS, ordinary least squares. ${ }^{*} p<0.05 .{ }^{* *} p<0.01 .{ }^{* * *} p<0.001$. 
et al. (2021) show that the stock of emigrant doctors increases less than proportionately with the number of physicians in the home country-that is, the physician emigration rate decreases with 'increases' in the number of domestic physicians. In our view this is not surprising, a rise in the number of domestic physicians-especially in poor and deprived areas characterized by scarcity of qualified healthcare personnel-improves the productivity of the labour force and the overall working conditions of healthcare workers. This in turn creates more incentives for doctors and nurses to stay in their home country rather than leaving. Combining this reasoning with our evidence on the positive relationship between foreign assistance and the number of physicians (Table 8), we can cautiously conclude that the

TAB LE 9 Mechanisms-cross-sectional correlations: Effect of health aid on health infrastructures (Source: WHO)

\begin{tabular}{|c|c|c|c|c|c|c|}
\hline & (1) & (2) & (3) & (4) & (5) & (6) \\
\hline Estimator & OLS & OLS & OLS & OLS & OLS & OLS \\
\hline $\begin{array}{l}\text { Dependent variable } \\
\text { (in log) }\end{array}$ & $\begin{array}{l}\text { Health } \\
\text { posts }\end{array}$ & $\begin{array}{l}\text { Health } \\
\text { centres }\end{array}$ & $\begin{array}{c}\text { District/rural } \\
\text { hospitals }\end{array}$ & $\begin{array}{r}\text { Provincial } \\
\text { hospitals }\end{array}$ & $\begin{array}{r}\text { Specialized } \\
\text { hospitals }\end{array}$ & $\begin{array}{l}\text { Number } \\
\text { hospitals }\end{array}$ \\
\hline Data source: & WHO & WHO & WHO & WHO & WHO & WHO \\
\hline \multicolumn{7}{|l|}{$\begin{array}{l}\text { Independent variables } \\
\text { (lagged at } t-1 \text { ) }\end{array}$} \\
\hline Log health ODA pc (o) & $\begin{array}{c}0.188 \\
(1.78)\end{array}$ & $\begin{array}{l}0.520^{* *} \\
(3.24)\end{array}$ & $0.269^{* *}(2.77)$ & $\begin{array}{r}0.384^{* * *} \\
(3.81)\end{array}$ & $0.233^{*}(2.31)$ & $\begin{array}{r}0.257^{* * *} \\
(4.23)\end{array}$ \\
\hline$N$ & 82 & 78 & 86 & 80 & 85 & 97 \\
\hline
\end{tabular}

Note: $t$ statistics are in parentheses. Robust standard errors are in parentheses. The dependent variables are expressed in per capita terms. In Column 6, for instance, the dependent variable is the log of the per capita number of hospitals in a given country at time $t$. ODA variable is lagged 1 year and is the average over 4 -year periods $(t-1$ to $t-4)$. The regressions include GDP per capita (log) and a conflict dummy as controls, whose coefficients are not reported. Data are from the World Health Organization and available for the years 2013 and 2010: hence, as dependent variable, we take the average of the 2010 and 2013 cross sections

Abbreviations: ODA, Official Development Assistance; OLS, ordinary least squares. ${ }^{*} p<0.05 .{ }^{* *} p<0.01 .{ }^{* * *} p<0.001$.

TAB LE 10 Mechanisms: Subtracting bilateral flows

\begin{tabular}{|c|c|c|c|c|}
\hline & (1) & & (3) & (4) \\
\hline Estimator & PPML & PPML & PPML & PPML \\
\hline Dep. variable & $\begin{array}{l}\text { Migration rate } \\
\text { nurses }\end{array}$ & $\begin{array}{l}\text { Migration rate } \\
\text { nurses }\end{array}$ & $\begin{array}{l}\text { Migration rate } \\
\text { doctors }\end{array}$ & $\begin{array}{l}\text { Migration rate } \\
\text { doctors }\end{array}$ \\
\hline Sample destinations & Whole & Whole & Whole & Whole \\
\hline Log minus bil. health ODA pc (o) & $-0.100^{*}(-2.29)$ & $-0.0980(-1.71)$ & $-0.0964^{* *}(-2.63)$ & $-0.0780^{*}(-1.96)$ \\
\hline Log bilateral health ODA pc (d to o) & & $-0.0113(-1.44)$ & & $0.0172^{*}(2.33)$ \\
\hline Log GDP Const. \$ PPP (o) & $-2.277^{* * *}(-7.53)$ & $-2.233^{* * *}(-7.96)$ & $-0.605^{*}(-2.14)$ & $-0.631^{*}(-2.20)$ \\
\hline N & 2,541 & 2,541 & 4,387 & 4,387 \\
\hline Destination-year FE & $x$ & $x$ & $x$ & $x$ \\
\hline Origin-destination FE & $x$ & $x$ & $x$ & $x$ \\
\hline Destinations & 18 & 18 & 23 & 23 \\
\hline Origins & 108 & 108 & 107 & 107 \\
\hline$\%$ Zeros & $23.6 \%$ & $23.6 \%$ & $16.7 \%$ & $16.7 \%$ \\
\hline
\end{tabular}

Note: $t$ statistics are in parentheses. The specification distinguishes between bilateral and non-bilateral health aid. In order to maintain the same sample size as in Tables 1 and 2, ODA is expressed in log form as $\ln (1+$ ODA). Therefore, the coefficients in this table should be interpreted as semi-elasticity rather than elasticity. All specifications include GDP per capita and Diaspora as controls.

${ }^{*} p<0.05 .{ }^{* *} p<0.01 .{ }^{* *} p<0.001$. 
rise in the number of domestic physicians induced by foreign aid leads to lower doctors' (and possibly also nurses') emigration rates.

Berthélemy et al. (2009) have pointed to another possible transmission mechanism. They demonstrate that bilateral aid relationships between donor and recipient can positively affect emigration. This occurs through a network effect, which is similar to the one known for migrant networks, as they give rise to regular contacts and exchange of information. To investigate the relevance of this channel, we re-estimate Equation 1 distinguishing between bilateral and non-bilateral components of health aid. The results reported in Table 10 suggest, in accordance with previous studies covering the general aid-migration link (Berthélemy et al., 2009; Lanati \& Thiele, 2018a), that there is evidence of network effects running through bilateral aid relations for the specific case of doctors, but not for nurses. The discrepancy between doctors and nurses tends to confirm the hypothesis put forward by Berthélemy et al. (2009) that network effects are expected to be stronger among more skilled people because; for example, they interact more intensively with experts from donor countries.

\section{5 | CONCLUDING REMARKS}

In this paper, we analysed how aid for health and changes in GDP per capita affect the emigration rates of doctors and nurses from developing countries. Our empirical results show that additional health aid and higher GDP per capita are both associated with lower emigration for both groups of medical workers. The estimated effects capture short- to medium-term variations over time within countries and would therefore still be consistent with the existence of a migration hump in the long term.

From a development policy perspective, the paper's findings imply that foreign assistance that is targeted at improving health infrastructure can help mitigate medical brain drain. The same is true for more general growthenhancing activities by various actors-for example, governments who provide the institutional framework, private enterprises who invest in new equipment, and donors who ideally complement local development initiatives. It has to be noted, however, that our estimates point to quantitatively modest impacts and therefore suggest only a minor role for development-oriented measures in containing the emigration of medical workers.

By focusing on conditions in countries of origin, our analysis neglects the destination country perspective even though OECD countries tend to have policy instruments in place that aim at attracting skilled people such as medical workers. Providing a detailed account of how destination countries use immigration policy in pursuit of their own interests, and combining this with the developmental perspective adopted in this paper, would be a fruitful avenue for future research. This would contribute to a more complete picture of the determinants of medical brain drain. Another interesting question for future work is whether local governments or NGOs could affect health infrastructure in a similar way as donors. Finally, it would be promising to investigate the impact of aid and income shocks. Negative aid shocks, for instance, may lead to cuts in healthcare spending, with implications for medical workers' incomes and workplace conditions.

\section{ACKNOWLEDGEMENTS}

We thank Christopher Parsons, Martin Ruhs and Claas Schneiderheinze and participants of the MPC webinar "Migration and Development: Revisiting the Migration Hump" for helpful comments and suggestions.

\section{FUNDING INFORMATION}

We thank Stiftung Mercator for financial support under project number PN 14-297.

\section{DATA AVAILABILITY STATEMENT}

Data used in this paper are openly available from public sources (see Table A4). 


\section{ORCID}

Mauro Lanati (iD https://orcid.org/0000-0001-9411-6845

\section{ENDNOTES}

${ }^{1}$ This is not to deny that OECD countries may also aim to attract foreign health personnel to fill gaps in their own health systems. See, for example, Adovor et al. (2021) for a recent account of how different immigration policy instruments affect physicians' migration patterns.

${ }^{2}$ Note that Clist and Restelli (2021) are mainly concerned with irregular migrant flows, for which they do not obtain robust evidence in favour of a negative association between GDP per capita and emigration.

${ }^{3}$ The time span is restricted by the information available for nurses migrating to the United States.

${ }^{4}$ Although the data on migration of health personnel are not perfectly comparable across OECD countries (OECD, 2019), it is reasonable to assume that changes over time can be compared. In addition, in the robustness section, we address potential inconsistencies in the measurement of emigration flows of medical workers across destinations by including the United States as the only country of destination. The results are qualitatively very similar to the baseline estimates, which we find reassuring.

${ }^{5}$ In the OECD Health database, missing values are indicated by empty cells, and zero values are indicated with 0 . The missing information means data are not available (either not provided by the country, or not available at all) and should not be replaced with a 0 .

${ }^{6}$ Tables A1 and A2 in the Appendix list the number of emigrating doctors and nurses as well as the respective emigration rates for all the countries of origin included in the regression analysis.

${ }^{7}$ We include the term $\sum_{j} M_{i j t}^{h}$ even though we do not have a complete set of origins for each destination because we deem this ratio as closest to the rate of medical brain drain proposed by Bhargava and Docquier (2008) and Moullan (2013). In a robustness check, we re-estimate our benchmark specification by omitting the term $\sum_{j} M_{i j t}^{h}$ in the denominator. The results are virtually unaffected; they are available upon request.

8 Table A3 in the Appendix lists the different components of aid for health.

${ }^{9}$ Results are similar when using averages of ODA over different periods.

${ }^{10}$ Multilateral resistance to migration indicates the fact that the volume of bilateral migration between country pairs depends not only on the barriers between them, but also on the barriers and relative attractiveness of all potential destinations. Not accounting for multilateral resistance to migration in the gravity framework could significantly bias in the estimated coefficients of the determinants of migration (Bertoli \& Moraga, 2013).

${ }^{11}$ Egger and Tarlea (2015) have shown that ignoring multiway clustering in a gravity setting leads to misleading inference, which appears to be particularly relevant under the Poisson pseudo maximum likelihood (PML)-generalized linear model (GLM) estimator we employ.

12 Table A6 reports the results of a robustness check in which missing values of the dependent variable are imputed by letting the number of nurses and doctors vary proportionally to a country's total population.

13 Adovor et al. (2021) obtain a considerably stronger negative effect of increases in GDP per capita on the emigration of physicians as compared with our estimates.

${ }^{14}$ Lanati and Thiele (2018a) find the same discrepancy between time series and cross-country estimates for the impact of total foreign aid on total emigration.

${ }^{15}$ Given the relatively low number of observations on bilateral emigration of nurses, we cannot extend the analysis over the 3-year lag.

${ }^{16}$ We use the affinity score s3un. Data are taken from the updated version of the "United Nations General Assembly Voting Data" dataset available in the Erik Voeten Harvard Dataverse webpage https://dataverse.harvard.edu/dataset.xhtml? persistentld=doi:10.7910/DVN/LEJUQZ.

17 The statistically not significant trade coefficient is in line with Lanati and Thiele (2018a).

18 See below for an analysis of a further potential network effect running through bilateral aid relations.

19 As in Nunn and Qian's (2014) baseline specifications, the Kleibergen-Paap F statistics fall between the Stock and Yogo critical values for a maximum bias in the IV of less than 15\% (critical value: 8.96 ) and less than 10\% (critical value: 16.38), respectively.

${ }^{20}$ Only the availability of hospital beds is not significantly affected by increases in health aid. 


\section{REFERENCES}

Abarcar, P., \& Theoharides, C. (2020). Medical worker migration and origin-country human capital: Evidence from US visa policy. SocArXiv Papers, (August, 3).

Adovor, E., Czaika, M., Docquier, F., \& Moullan, Y. (2021). Medical brain drain: How many, where, and why? Journal of Health Economics, 76, 102409. https://doi.org/10.1016/j.jhealeco.2020.102409

Alesina, A., \& Dollar, D. (2000). Who gives foreign aid to whom and why? Journal of Economic Growth, 5(1), 33-63. https:// doi.org/10.1023/A:1009874203400

Ariu, A., Docquier, F., \& Squicciarini, M. (2016). Governance quality and net migration flows. Regional Science and Urban Economics, 60, 238-248. https://doi.org/10.1016/j.regsciurbeco.2016.07.006

Astor, A., Akhtar, T., Matallana, M. A., Muthuswamy, V., Oluwu, F. A., Tallo, V., \& Lie, R. K. (2005). Physician migration: Views from professionals in Columbia, Nigeria, India, Pakistan, and the Philippines. Social Science and Medicine, 61, 2492-2500. https://doi.org/10.1016/j.socscimed.2005.05.003

Bazzi, S. (2017). Wealth heterogeneity and the income elasticity of migration. American Economic Journal: Applied Economics, 9(2), 219-255.

Beine, M., Bertoli, S., \& Moraga, J. F. H. (2015). A practitioners' guide to gravity models of international migration. The World Economy, 39(4), 496-512.

Beine, M., \& Parsons, C. (2015). Climatic factors as determinants of international migration. Scandinavian Journal of Economics, 117(2), 723-767. https://doi.org/10.1111/sjoe.12098

Beine, M., \& Parsons, C. (2017). Climatic factors as determinants of international migration: Redux. CESifo Economic Studies, 63(4), 386-402. https://doi.org/10.1093/cesifo/ifx017

Bencek, D., \& Schneiderheinze, C. (2020). Higher economic growth in poor countries, lower migration flows to the OECD: Revisiting the migration hump with panel data (No. 2145). Kiel Working Paper.

Berthélemy, J.-C., Beuran, M., \& Maurel, M. (2009). Aid and migration: Substitutes or complements? World Development, 37(10), 1589-1599. https://doi.org/10.1016/j.worlddev.2009.02.002

Bertoli, S., \& Moraga, J. F. H. (2013). Multilateral resistance to migration. Journal of Development Economics, 102(May), 79-100. https://doi.org/10.1016/j.jdeveco.2012.12.001

Bertoli, S., \& Moraga, J. F. H. (2015). The size of the cliff at the border. Regional Science and Urban Economics, 51, 1-6. https://doi.org/10.1016/j.regsciurbeco.2014.12.002

Bhagwati, J., \& Hamada, K. (1974). The brain drain, international integration of markets for professionals and unemployment: A theoretical analysis. Journal of Development Economics, 1(1), 19-42. https://doi.org/10.1016/0304-3878(74)90020-0

Bhargava, A., \& Docquier, F. (2008). HIV pandemic, medical brain drain, and economic development in sub-Saharan Africa. World Bank Economic Review, 22, 345-366. https://doi.org/10.1093/wber/lhn005

Botezat, A., \& Ramos, R. (2020). Physicians' brain drain-A gravity model of migration flows. Globalization and Health, 16(1), 1-13.

Cameron, A. C., Gelbach, J. B., \& Miller, D. L. (2011). Robust inference with multiway clustering. Journal of Business and Economic Statistics, 29(2), 238-249. https://doi.org/10.1198/jbes.2010.07136

Campaniello, N. (2014). The causal effect of trade on migration: Evidence from countries of the Euro-Mediterranean partnership. Labour Economics, 30(C), 223-233. https://doi.org/10.1016/j.labeco.2014.04.006

Cattaneo, C., \& Peri, G. (2016). The migration response to increasing temperatures. Journal of Development Economics, 122, 127-146. https://doi.org/10.1016/j.jdeveco.2016.05.004

Chauvet, L., Gubert, F., \& Mesplé-Somps, S. (2013). Aid, remittances, medical brain drain and child mortality: Evidence using inter and intra-country data. The Journal of Development Studies, 49(6), 801-818.

Clemens, M. A. (2014). Does development reduce migration? In International Handbook on Migration and Economic Development (Vol. 8592) (pp. 152-185). Edward Elgar Publishing.

Clemens, M. A. (2020). The emigration life cycle: How Development shapes emigration from poor countries. Center for Global Development Working Paper 540, (August 2020).

Clemens, M. A., \& McKenzie, D. (2009). Think again: Brain drain. Foreign Policy, (October 22).

Clist, P., \& Restelli, G. (2021). Development aid and international migration to Italy: Does aid reduce irregular flows? The World Economy, 44(5), 1281-1311.

Dreher, A., Fuchs, A., \& Langlotz, S. (2019). The effects of foreign aid on refugee flows. European Economic Review, 112, 127-147. https://doi.org/10.1016/j.euroecorev.2018.12.001

Dreher, A., \& Langlotz, S. (2020). Aid and growth. New evidence using an excludable instrument. Canadian Journal of Economics, 53(3), 1162-1198. https://doi.org/10.1111/caje.12455

Dustmann, C., \& Okatenko, A. (2014). Out-migration, wealth constraints, and the quality of local amenities. Journal of Development Economics, 110, 52-63. https://doi.org/10.1016/j.jdeveco.2014.05.008

Egger, P. H., \& Tarlea, F. (2015). Multi-way clustering estimation of standard errors in gravity models. Economics Letters, 134, 144-147. https://doi.org/10.1016/j.econlet.2015.06.023 
Faye, M., \& Niehaus, P. (2012). Political aid cycles. American Economic Review, 102(7), 3516-3530. https://doi.org/10.1257/ aer.102.7.3516

Gamso, J., \& Yuldashev, F. (2018a). Does rural development aid reduce international migration? World Development, 110, 268-282. https://doi.org/10.1016/j.worlddev.2018.05.035

Gamso, J., \& Yuldashev, F. (2018b). Targeted foreign aid and international migration: Is development-promotion an effective immigration policy? International Studies Quarterly, 62(4), 809-820. https://doi.org/10.1093/isq/sqy029

Hatton, T. J., \& Williamson, J. G. (2002). What fundamentals drive world migration? NBER Working Paper 9159. National Bureau of Economic Research, Inc.

Kangasniemi, M., Winters, L. A., \& Commander, S. (2007). Is the medical brain drain beneficial? Evidence from overseas doctors in the UK. Social Science and Medicine, 65, 915-923. https://doi.org/10.1016/j.socscimed.2007.04.021

Kotsadam, A., Østby, G., Rustad, S. A., Forø Tollefsen, A., \& Urdal, H. (2018). Development aid and infant mortality: Micro-level evidence from Nigeria. World Development, 105(May), 59-69. https://doi.org/10.1016/j.worlddev.2017. 12.022

Lahiri, S., \& Raimondos-Møller, P. (2000). Lobbying by ethnic groups and aid allocation. Economic Journal, 129, 879-900.

Lanati, M., \& Thiele, R. (2018a). The impact of foreign aid on migration revisited. World Development, 111, 59-74. https:// doi.org/10.1016/j.worlddev.2018.06.021

Lanati, M., \& Thiele, R. (2018b). Foreign assistance and migration choices: Disentangling the channels. Economics Letters, 172, 148-151. https://doi.org/10.1016/j.econlet.2018.09.002

Lanati, M., \& Thiele, R. (2020a). Foreign assistance and emigration: Accounting for the role of non-transferred aid. The World Economy, 43(7), 1951-1976. https://doi.org/10.1111/twec.12914

Lanati, M., \& Thiele, R. (2020b). International student flows from developing countries: Do donors have an impact? Economics of Education Review, 77(August), 101997. https://doi.org/10.1016/j.econedurev.2020.101997

Mishra, P., \& Newhouse, D. (2009). Does health aid matter? Journal of Health Economics, 28, 855-872. https://doi.org/10. 1016/j.jhealeco.2009.05.004

Moullan, Y. (2013). Can foreign health assistance reduce the medical brain drain? Journal of Development Studies, 49(10), 1436-1452. https://doi.org/10.1080/00220388.2013.794261

Nunn, N., \& Qian, N. (2014). US food aid and civil conflict. American Economic Review, 104(6), 1630-1666. https://doi.org/ 10.1257/aer.104.6.1630

OECD. (2015). International migration outlook 2015. Paris: OECD Publishing. https://doi.org/10.1787/migr_outlook2015-en

OECD. (2019). OECD Health Statistics 2019 Definitions, Sources and Methods, available at: https://www.oecd.org/els/ health-systems/Table-of-Content-Metadata-OECD-Health-Statistics-2019.pdf

Qian, N. (2015). Making progress on foreign aid. Annual Review of Economics, 7(1), 277-308. https://doi.org/10.1146/ annurev-economics-080614-115553

Silva, J. S., \& Tenreyro, S. (2006). The log of gravity. The Review of Economics and Statistics, 88(4), 641-658. https://doi.org/ 10.1162/rest.88.4.641

Stark, O., Haldenstein, C., \& Prskawetz, A. (1997). A brain gain with a brain drain. Economic Letters, 55, 227-234. https:// doi.org/10.1016/S0165-1765(97)00085-2

World Health Organization (WHO). (2020). Global Health Observatory (GHO) data.

How to cite this article: Lanati, M., \& Thiele, R. (2021). Aid for health, economic growth, and the emigration of medical workers. Journal of International Development, 1-29. https://doi.org/10.1002/jid.3568 
TABLE A1 Countries of origin in the sample: Emigration of nurses (average 2006-2015)

\begin{tabular}{|c|c|c|c|c|}
\hline $\begin{array}{l}\text { Destination } \\
\text { Origin }\end{array}$ & $\begin{array}{l}\text { Emigration flows } \\
\text { All }\end{array}$ & $\begin{array}{l}\text { Emigration rates } \\
\text { (per thousand) } \\
\text { All }\end{array}$ & $\begin{array}{l}\text { Emigration flows } \\
\text { USA }\end{array}$ & $\begin{array}{l}\text { Emigration rates } \\
\text { (per thousand) } \\
\text { USA }\end{array}$ \\
\hline Philippines & 8180.7 & 20.95703 & 6860.1 & 17.22766 \\
\hline India & 2737.1 & 1.758528 & 1444.1 & 0.9585693 \\
\hline China & 274.2 & 0.1503812 & 175.3 & 0.0977455 \\
\hline Nigeria & 226.3 & 1.871048 & 120 & 0.9771218 \\
\hline Jamaica & 142.7 & 40.43991 & 123 & 35.13354 \\
\hline Peru & 142 & 3.038256 & 9 & 0.1942262 \\
\hline Ukraine & 114.7 & 0.340169 & 58.6 & 0.1716908 \\
\hline Nepal & 112.6 & 6.627877 & 66.7 & 3.009881 \\
\hline Albania & 96.5 & 7.225455 & 2.6 & 0.1956698 \\
\hline Iran & 79.9 & 0.6064556 & 31.7 & 0.2393595 \\
\hline Kenya & 70.3 & 3.447183 & 54.1 & 2.551132 \\
\hline Pakistan & 65.3 & 0.9926745 & 19.5 & 0.272438 \\
\hline Haiti & 62.9 & 14.77263 & 37 & 9.309366 \\
\hline Serbia & 59.8 & 1.330521 & 1.4 & 0.0308062 \\
\hline South Africa & 58.2 & 0.2644542 & 20.8 & 0.0957353 \\
\hline Bosnia and Herzegovina & 55.7 & 2.651538 & 3.3 & 0.1600073 \\
\hline Jordan & 55.3 & 2.418612 & 17.2 & 0.816414 \\
\hline Brazil & 54.4 & 0.043777 & 13.1 & 0.01074 \\
\hline Ghana & 49.9 & 2.389431 & 29.5 & 1.271906 \\
\hline Thailand & 45.8 & 0.4001828 & 39.9 & 0.3545504 \\
\hline Croatia & 45.6 & 1.635021 & 0.8 & 0.0305131 \\
\hline Lebanon & 45 & 4.868343 & 16.5 & 1.991756 \\
\hline Colombia & 43.7 & 1.280499 & 16.2 & 0.4791895 \\
\hline Ethiopia & 37.5 & 1.490754 & 35.3 & 1.388901 \\
\hline Tunisia & 32 & 1.281189 & 0 & 0 \\
\hline Moldova & 31.3 & 1.380396 & 2.8 & 0.1246556 \\
\hline Zimbabwe & 29.1 & 1.775189 & 3.8 & 0.231459 \\
\hline Zambia & 22.4 & 3.400619 & 3.8 & 0.574237 \\
\hline Uzbekistan & 21.8 & 0.0689952 & 14 & 0.0441387 \\
\hline Mexico & 21.3 & 0.0821314 & 20.1 & 0.0774789 \\
\hline Cameroon & 19.7 & 1.740258 & 13.4 & 1.152891 \\
\hline Algeria & 17.7 & 0.2413027 & 0.2 & 0.0034155 \\
\hline Mauritius & 14.2 & 3.955087 & 2.9 & 0.8787879 \\
\hline Armenia & 14.1 & 0.9284419 & 13.5 & 0.8888873 \\
\hline Paraguay & 13.9 & 1.792687 & 0 & 0 \\
\hline Belarus & 13.5 & 0.1456247 & 7.4 & 0.0802217 \\
\hline Argentina & 13.1 & 0.1643732 & 3.4 & 0.0342739 \\
\hline Saudi Arabia & 12 & 0.1002258 & 7.8 & 0.05315 \\
\hline
\end{tabular}


TABLE A1 (Continued)

\begin{tabular}{|c|c|c|c|c|}
\hline $\begin{array}{l}\text { Destination } \\
\text { Origin }\end{array}$ & $\begin{array}{l}\text { Emigration flows } \\
\text { All }\end{array}$ & $\begin{array}{l}\text { Emigration rates } \\
\text { (per thousand) } \\
\text { All }\end{array}$ & $\begin{array}{l}\text { Emigration flows } \\
\text { USA }\end{array}$ & $\begin{array}{l}\text { Emigration rates } \\
\text { (per thousand) } \\
\text { USA }\end{array}$ \\
\hline Guyana & 11.5 & 12.33052 & 9.7 & 10.42093 \\
\hline Morocco & 10.9 & 0.3678156 & 0.8 & 0.0283095 \\
\hline Sri Lanka & 10.5 & 0.3554476 & 2.6 & 0.0834831 \\
\hline Kazakhstan & 10.4 & 0.0810475 & 1.9 & 0.0151688 \\
\hline Dominican Republic & 9.2 & 0.7739995 & 2.6 & 0.2213296 \\
\hline Georgia & 9.1 & 0.6310956 & 6.8 & 0.4768947 \\
\hline Turkey & 8.8 & 0.0674964 & 3.7 & 0.0284758 \\
\hline Myanmar & 8.6 & 0.3813467 & 8.3 & 0.3683174 \\
\hline Ecuador & 8.3 & 0.3187849 & 1.7 & 0.0673425 \\
\hline Indonesia & 7.9 & 0.0537667 & 4.8 & 0.0322645 \\
\hline Chile & 7.6 & 5.919086 & 5.2 & 3.846919 \\
\hline Sierra Leone & 7.6 & 7.035678 & 5 & 4.62423 \\
\hline Eritrea & 7.4 & 2.59919 & 6.4 & 2.099469 \\
\hline Gambia & 6.6 & 6.785609 & 4.8 & 4.119517 \\
\hline North Macedonia & 6.5 & 0.7639533 & 0.4 & 0.0461547 \\
\hline Bolivia & 5.9 & 0.7384278 & 0.2 & 0.0299439 \\
\hline Malaysia & 5.9 & 0.0904427 & 4 & 0.0557578 \\
\hline Barbados & 5.8 & 4.032954 & 1.8 & 1.274562 \\
\hline Côte d'Ivoire & 5.8 & 0.5508842 & 0 & 0 \\
\hline Uganda & 5.8 & 0.1675797 & 3.8 & 0.1154601 \\
\hline Panama & 5.7 & 0.7343604 & 3.3 & 0.4339516 \\
\hline Trinidad and Tobago & 5.6 & 1.237301 & 4.5 & 0.9956094 \\
\hline Egypt & 5 & 0.0332034 & 4.1 & 0.0272123 \\
\hline Bangladesh & 4.8 & 0.1925811 & 1 & 0.0297319 \\
\hline Suriname & 4.8 & 2.598411 & 0.1 & 0.0515836 \\
\hline Venezuela & 4.8 & 0.1467497 & 2.2 & 0.0667287 \\
\hline Belize & 4.4 & 9.522161 & 4.4 & 9.522161 \\
\hline Oman & 4 & 0.2850941 & 3.3 & 0.2187251 \\
\hline Malawi & 3.8 & 0.8862253 & 0.4 & 0.078309 \\
\hline Liberia & 3.5 & 4.780256 & 3.1 & 4.164471 \\
\hline Costa Rica & 3.2 & 0.8581653 & 2.8 & 0.7509885 \\
\hline Congo & 3.1 & 0.6464056 & 0.3 & 0.0463896 \\
\hline Grenada & 2.5 & 6.268998 & 2.4 & 6.177742 \\
\hline Fiji & 2.4 & 1.040033 & 0.5 & 0.234008 \\
\hline Saint Lucia & 2.4 & 7.864879 & 2.2 & 7.225972 \\
\hline Kyrgyzstan & 2.3 & 0.0757268 & 2.2 & 0.0723151 \\
\hline Iraq & 2.1 & 0.0381274 & 0.1 & 0.001996 \\
\hline Montenegro & 2 & 0.6070369 & 0.2 & $\begin{array}{l}0.0607304 \\
\text { (Continues) }\end{array}$ \\
\hline
\end{tabular}


TABLE A1 (Continued)

\begin{tabular}{|c|c|c|c|c|}
\hline Saint Vincent and the Grenadines & 2 & 5.330025 & 1.6 & 4.2294 \\
\hline Uruguay & 2 & 0.1163822 & 0.7 & 0.0361962 \\
\hline Dominica & 1.8 & 4.117162 & 1.7 & 3.888329 \\
\hline Tanzania & 1.8 & 0.1401211 & 1.6 & 0.1266371 \\
\hline El Salvador & 1.7 & 0.2304212 & 1.5 & 0.2131381 \\
\hline Burkina Faso & 1.6 & 0.3376669 & 0.6 & 0.1121517 \\
\hline Democratic Republic of the Congo & 1.6 & 0.0607717 & 0.3 & 0.0120173 \\
\hline Rwanda & 1.5 & 0.2088685 & 0.9 & 0.1261212 \\
\hline Azerbaijan & 1.4 & 0.0215921 & 0.6 & 0.0091657 \\
\hline Mongolia & 1.4 & 0.1483296 & 1.2 & 0.1283927 \\
\hline Tajikistan & 1.4 & 0.053328 & 1.1 & 0.0401001 \\
\hline Antigua and Barbuda & 1.3 & 4.354342 & 1.2 & 4.008681 \\
\hline Botswana & 1.3 & 0.2376453 & 0.5 & 0.094316 \\
\hline Burundi & 1.2 & 0.2590637 & 0.4 & 0.0710422 \\
\hline Turkmenistan & 1.2 & 0.0470595 & 1.1 & 0.0429275 \\
\hline Afghanistan & 1 & 0.0805427 & 0.2 & 0.0115895 \\
\hline Guatemala & 0.9 & 0.0737653 & 0.8 & 0.0651893 \\
\hline Nicaragua & 0.9 & 0.1192116 & 0.5 & 0.0668522 \\
\hline Seychelles & 0.8 & 1.929535 & 0 & 0 \\
\hline Viet Nam & 0.8 & 0.0119424 & 0.3 & 0.0054131 \\
\hline Honduras & 0.5 & 0.0824309 & 0.5 & 0.0824309 \\
\hline Niger & 0.5 & 0.2511229 & 0.2 & 0.1088159 \\
\hline Senegal & 0.5 & 0.0969995 & 0.2 & 0.0533526 \\
\hline Benin & 0.4 & 0.0724381 & 0.2 & 0.0346921 \\
\hline Sudan & 0.4 & 0.0170096 & 0.2 & 0.0085078 \\
\hline Angola & 0.3 & 0.0119913 & 0 & 0 \\
\hline Mauritania & 0.3 & 0.1332767 & 0 & 0 \\
\hline Togo & 0.3 & 0.1363779 & 0.1 & 0.0806452 \\
\hline Cape Verde & 0.2 & 0.4081785 & 0 & 0 \\
\hline Chad & 0.2 & 0.063674 & 0.2 & 0.063674 \\
\hline Lesotho & 0.2 & 0.1613617 & 0.1 & 0.0825861 \\
\hline Palau & 0.2 & 1.797824 & 0.2 & 1.797824 \\
\hline
\end{tabular}

Note: Data are from the Health Workforce Migration dataset (OECD). Emigration Rates are calculated as the average of the ratio between total nurse emigration and nurse population for a given origin over the period 2006-2015. Countries that exhibit the 10 highest emigration rates are in bold. 
TABLE A2 Countries of origin in the sample: Emigration of doctors (average 2006-2015)

\begin{tabular}{|c|c|c|c|c|}
\hline $\begin{array}{l}\text { Destination } \\
\text { Origin }\end{array}$ & $\begin{array}{l}\text { Emigration flows } \\
\text { All }\end{array}$ & $\begin{array}{l}\text { Emigration rates } \\
\text { (per thousand) } \\
\text { All }\end{array}$ & $\begin{array}{l}\text { Emigration flows } \\
\text { USA }\end{array}$ & $\begin{array}{l}\text { Emigration rates } \\
\text { (per thousand) } \\
\text { USA }\end{array}$ \\
\hline India & 2304.8 & 2.882875 & 1433.4 & 1.796239 \\
\hline Pakistan & 1146.7 & 7.60231 & 400.9 & 2.699812 \\
\hline Nigeria & 412 & 8.109043 & 120.4 & 2.372758 \\
\hline Egypt & 398.2 & 6.448642 & 107.6 & 1.767312 \\
\hline Colombia & 305.5 & 3.872108 & 91.8 & 1.26513 \\
\hline China & 302.4 & 0.1507115 & 208.8 & 0.1053215 \\
\hline Iraq & 279.7 & 12.90946 & 56.3 & 2.407793 \\
\hline Saudi Arabia & 277.2 & 4.316364 & 48.4 & 0.7068645 \\
\hline Iran & 266.6 & 3.892691 & 130 & 1.897496 \\
\hline South Africa & 214.4 & 5.653528 & 8 & 0.212638 \\
\hline Philippines & 213.7 & 1.825997 & 174.9 & 1.500527 \\
\hline Sudan & 204.8 & 15.3922 & 26.3 & 2.043601 \\
\hline Ukraine & 200.3 & 1.309034 & 41.1 & 0.2630349 \\
\hline Mexico & 194.5 & 0.7783738 & 147.4 & 0.5903127 \\
\hline Ecuador & 183.4 & 6.486145 & 31 & 1.168861 \\
\hline Sri Lanka & 177.3 & 11.35529 & 9 & 0.601445 \\
\hline Jordan & 149.6 & 8.614302 & 78.3 & 4.593152 \\
\hline Dominican Republic & 139.5 & 10.22293 & 103 & 7.746138 \\
\hline Lebanon & 138.7 & 11.21378 & 101.1 & 8.229341 \\
\hline Algeria & 127.2 & 2.141443 & 2.8 & 0.061832 \\
\hline Brazil & 126.6 & 0.350875 & 47.4 & 0.1336313 \\
\hline Argentina & 125.8 & 0.8122889 & 30.8 & 0.2117717 \\
\hline Venezuela & 108.9 & 1.932402 & 48.4 & 0.8699451 \\
\hline Bangladesh & 108.5 & 1.96693 & 40.2 & 0.7524307 \\
\hline Nepal & 108.2 & 9.49886 & 82.5 & 7.418213 \\
\hline Peru & 98.2 & 2.881515 & 53.4 & 1.499017 \\
\hline Serbia & 96.5 & 4.372436 & 12.9 & 0.5898249 \\
\hline Libya & 92.6 & 8.019333 & 22.5 & 1.871946 \\
\hline Croatia & 69.7 & 5.436932 & 4.4 & 0.3717145 \\
\hline Myanmar & 68.8 & 2.622294 & 40.6 & 1.544932 \\
\hline Tunisia & 65.1 & 4.813971 & 0.8 & 0.0676192 \\
\hline Turkey & 64.2 & 0.5306244 & 34.4 & 0.284619 \\
\hline Thailand & 51.6 & 2.152255 & 31.2 & 1.319654 \\
\hline Jamaica & 42.4 & 36.37971 & 21.3 & 18.03208 \\
\hline Ethiopia & 41.9 & 13.59927 & 35.5 & 11.32594 \\
\hline Bolivia & 41.3 & 6.707798 & 6.4 & 1.318226 \\
\hline Belarus & 39.4 & 1.11326 & 13.9 & 0.3980393 \\
\hline Morocco & 38.8 & 1.85496 & 4 & 0.1987994 \\
\hline
\end{tabular}


TABLE A2 (Continued)

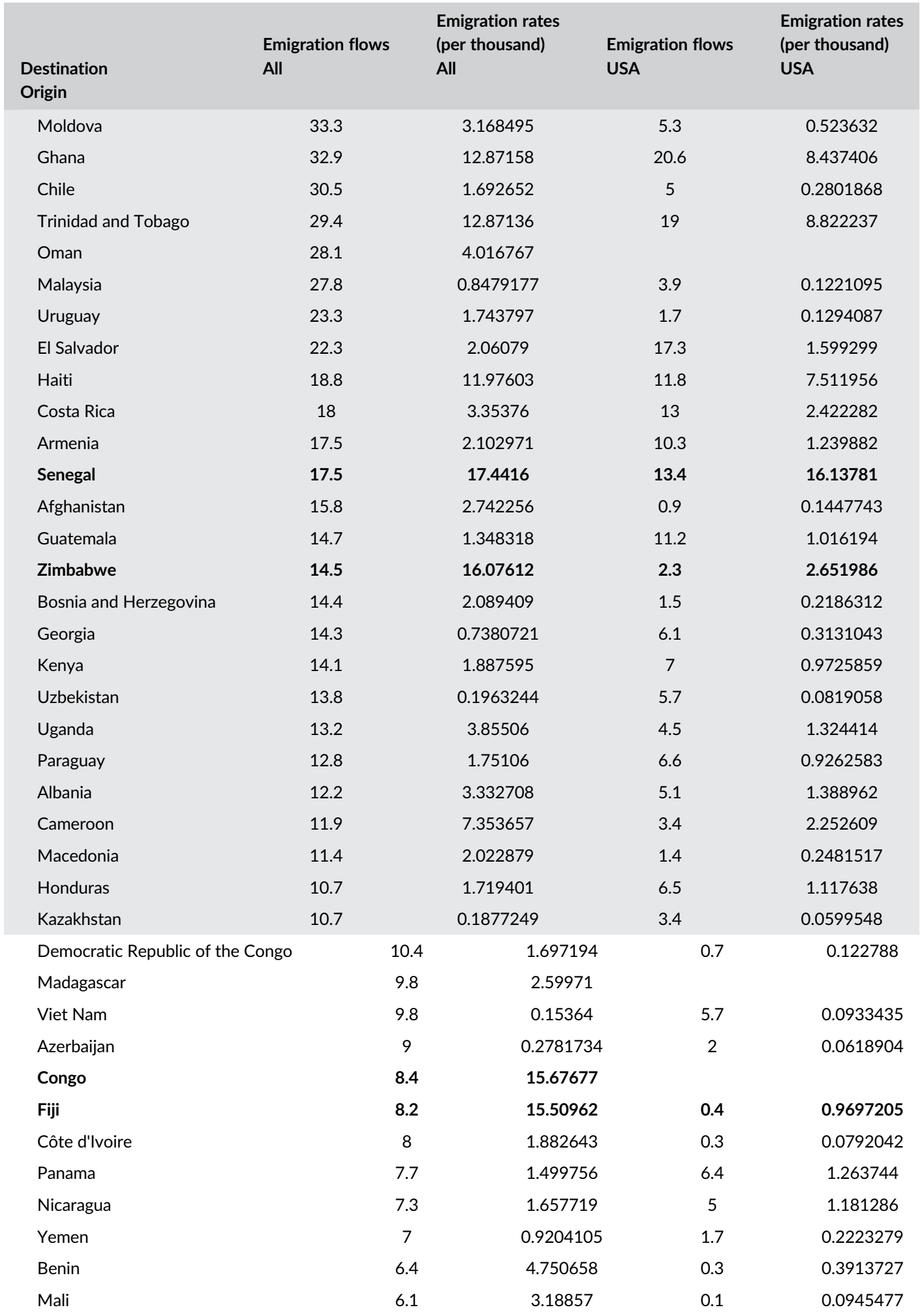


TABLE A2 (Continued)

\begin{tabular}{|c|c|c|c|c|}
\hline Togo & 6.1 & 10.11518 & 0.3 & 1.053733 \\
\hline Indonesia & 5.8 & 0.1204532 & 3.7 & 0.0778868 \\
\hline Mauritius & 5.6 & 3.042079 & 3.1 & 1.682254 \\
\hline Barbados & 5.3 & 9.047723 & 4.4 & 7.649174 \\
\hline Kyrgyzstan & 5.2 & 0.4611956 & 1.8 & 0.1537166 \\
\hline Suriname & 5.1 & 12.47111 & & \\
\hline Guyana & 5 & 17.43943 & 3.1 & 10.88167 \\
\hline Tanzania & 4.2 & 2.899789 & 1.8 & 1.297851 \\
\hline Guinea & 4.1 & 4.246116 & 0.2 & 0.2116307 \\
\hline Zambia & 3.9 & 4.385025 & 0.9 & 1.14264 \\
\hline Burundi & 3.5 & 7.980649 & 0.1 & 0.3667482 \\
\hline Mongolia & 2.4 & 0.290329 & 0.6 & 0.0772801 \\
\hline Seychelles & 2.3 & 24.19407 & 2 & 20.92074 \\
\hline Rwanda & 2.1 & 1.698783 & 0.1 & 0.0905797 \\
\hline Tajikistan & 2 & 0.1489328 & 0.9 & 0.0658948 \\
\hline Gabon & 1.9 & 3.1007 & 0.1 & 0.1452785 \\
\hline Malawi & 1.8 & 6.695682 & 0.1 & 0.3697834 \\
\hline Sierra Leone & 1.7 & 13.80994 & 0.3 & 1.908212 \\
\hline Montenegro & 1.6 & 1.207785 & & \\
\hline Niger & 1.6 & 2.444605 & 0.2 & 0.689688 \\
\hline Samoa & 1.2 & 15.21255 & 0.9 & 11.56805 \\
\hline Burkina Faso & 1.1 & 1.249676 & & \\
\hline Central African Republic & 0.9 & 3.436592 & & \\
\hline Turkmenistan & 0.9 & 0.0650089 & 0.3 & 0.0208804 \\
\hline Cambodia & 0.6 & 0.1950206 & 0.1 & 0.0303582 \\
\hline Mozambique & 0.6 & 0.5499114 & & \\
\hline Papua New Guinea & 0.6 & 1.494658 & 0.1 & 0.2496391 \\
\hline Angola & 0.5 & 0.1812168 & & \\
\hline Liberia & 0.4 & 4.153479 & 0.3 & 3.422485 \\
\hline Mauritania & 0.3 & 0.6950803 & & \\
\hline Chad & 0.1 & 0.1542417 & & \\
\hline
\end{tabular}

Note: Data are from the Health Workforce Migration dataset (OECD). Emigration Rates are calculated as the average of the ratio between total doctor emigration and doctor population for a given origin over the period 2006-2015. Dominica, Grenada, Antigua and Barbuda, Saint Kitts and Nevis, Belize, Saint Vincent and Grenadines and Saint Lucia are dropped because they exhibit emigration flows that are disproportionate with respect to the country's population and therefore do not appear in the list of countries of origin. Dominica and Grenada are the second and fourth overall country of origin of doctors, respectively, while the other countries lie above the 70th percentile in the distribution of doctors' emigration in at least 1 year of the covered time span (2006-2015). Countries that exhibit the 10 highest emigration rates are in bold. 
TABLE A3 Official Development Assistance (ODA) health sectors

\begin{tabular}{|c|c|c|c|c|}
\hline $\begin{array}{l}\text { DAC } \\
5 \\
\text { code }\end{array}$ & $\begin{array}{l}\text { CRS } \\
\text { code }\end{array}$ & $\begin{array}{l}\text { Voluntary } \\
\text { code }\end{array}$ & Description & Clarifications/additional notes on coverage \\
\hline 120 & & & Health & \\
\hline \multirow[t]{6}{*}{121} & & & Health, general & \\
\hline & 12110 & & $\begin{array}{l}\text { Health policy and } \\
\text { administrative } \\
\text { management }\end{array}$ & $\begin{array}{l}\text { Health sector policy, planning and programmes; aid to } \\
\text { health ministries, public health administration; institution } \\
\text { capacity building and advice; medical insurance } \\
\text { programmes; including health system strengthening and } \\
\text { health governance; unspecified health activities. }\end{array}$ \\
\hline & & 12196 & $\begin{array}{l}\text { Health statistics and } \\
\text { data }\end{array}$ & $\begin{array}{l}\text { Collection, production, management and dissemination of } \\
\text { statistics and data related to health. Includes health } \\
\text { surveys, establishment of health databases, data } \\
\text { collection on epidemics, etc. }\end{array}$ \\
\hline & 12181 & & $\begin{array}{c}\text { Medical education/ } \\
\text { training }\end{array}$ & Medical education and training for tertiary level services. \\
\hline & 12182 & & Medical research & $\begin{array}{l}\text { General medical research (excluding basic health research } \\
\text { and research for prevention and control of NCDs } \\
[12382]) .\end{array}$ \\
\hline & 12191 & & Medical services & $\begin{array}{l}\text { Laboratories, specialized clinics and hospitals (including } \\
\text { equipment and supplies); ambulances; dental services; } \\
\text { medical rehabilitation. Excludes noncommunicable } \\
\text { diseases (123xx). }\end{array}$ \\
\hline \multirow[t]{4}{*}{122} & & & Basic health & \\
\hline & 12220 & & Basic healthcare & $\begin{array}{c}\text { Basic and primary healthcare programmes; paramedical and } \\
\text { nursing care programmes; supply of drugs, medicines and } \\
\text { vaccines related to basic healthcare; activities aimed at } \\
\text { achieving universal health coverage. }\end{array}$ \\
\hline & 12230 & & $\begin{array}{l}\text { Basic health } \\
\text { infrastructure }\end{array}$ & $\begin{array}{l}\text { District-level hospitals, clinics and dispensaries and related } \\
\text { medical equipment; excluding specialized hospitals and } \\
\text { clinics (12191). }\end{array}$ \\
\hline & 12240 & & Basic nutrition & $\begin{array}{l}\text { Micronutrient deficiency identification and } \\
\text { supplementation; Infant and young child feeding } \\
\text { promotion including exclusive breastfeeding; Non- } \\
\text { emergency management of acute malnutrition and other } \\
\text { targeted feeding programmes (including complementary } \\
\text { feeding); Staple food fortification including salt } \\
\text { iodization; Nutritional status monitoring and national } \\
\text { nutrition surveillance; Research, capacity building, policy } \\
\text { development, monitoring and evaluation in support of } \\
\text { these interventions. Use code } 11250 \text { for school feeding } \\
\text { and } 43,072 \text { for household food security. }\end{array}$ \\
\hline & 12250 & & $\begin{array}{l}\text { Infectious disease } \\
\text { control }\end{array}$ & $\begin{array}{l}\text { Immunization; prevention and control of infectious and } \\
\text { parasite diseases, except malaria (12262), tuberculosis } \\
\text { (12263), HIV/AIDS and other STDs (13040). It includes } \\
\text { diarrheal diseases, vector-borne diseases (e.g. river } \\
\text { blindness and guinea worm), viral diseases, mycosis, } \\
\text { helminthiasis, zoonosis, diseases by other bacteria and } \\
\text { viruses, pediculosis, etc. }\end{array}$ \\
\hline
\end{tabular}


TABLE A3 (Continued)

\begin{tabular}{|c|c|c|c|c|}
\hline $\begin{array}{l}\text { DAC } \\
5 \\
\text { code }\end{array}$ & $\begin{array}{l}\text { CRS } \\
\text { code }\end{array}$ & $\begin{array}{l}\text { Voluntary } \\
\text { code }\end{array}$ & Description & Clarifications/additional notes on coverage \\
\hline & 12261 & & Health education & $\begin{array}{l}\text { Information, education and training of the population for } \\
\text { improving health knowledge and practices; public health } \\
\text { and awareness campaigns; promotion of improved } \\
\text { personal hygiene practices, including use of sanitation } \\
\text { facilities and handwashing with soap. }\end{array}$ \\
\hline & 12262 & & Malaria control & Prevention and control of malaria. \\
\hline & 12263 & & Tuberculosis control & Immunization, prevention and control of tuberculosis. \\
\hline & 12281 & & $\begin{array}{c}\text { Health personnel } \\
\text { development }\end{array}$ & Training of health staff for basic healthcare services. \\
\hline
\end{tabular}

TAB LE A4 Variables used and related sources

\begin{tabular}{|c|c|c|}
\hline Variable & Short description & Source \\
\hline \multicolumn{3}{|l|}{ Dependent variable } \\
\hline $\begin{array}{l}\text { Health workforce } \\
\text { emigration rates }\end{array}$ & $\begin{array}{l}\text { Bilateral Emigration Flows of Doctors and } \\
\text { Nurses divided by the respective Population } \\
\text { in their country of origin }\end{array}$ & $\begin{array}{l}\text { Number of nurses who have obtained a } \\
\text { recognized qualification in nursing/ } \\
\text { doctors who have obtained their first } \\
\text { medical qualification (degree) in another } \\
\text { country and are receiving a new } \\
\text { authorization in a given year to practice } \\
\text { in the receiving country. }\end{array}$ \\
\hline
\end{tabular}

Explanatory variables

ODA Health

Sector, Total

Total transferred ODA received by country $i$ from all donors in the Health Sector, normalized by the total population of country $i$, gross disbursements in Constant US dollars (2 years average).

GDP Per Capita GDP per capita, expressed in PPP constant US\$ (2011 prices)

\section{Diaspora \\ Governance
Quality}

Conflict

Natural Disasters
Stock of migrants born in country $n$ and resident in country $i$ at time $t-1$. Values for intermediate years are linearly interpolated.

A synthetic indicator of quality of governance based on a principal component analysis (PCA) of the six World Bank Governance Indicators (Voice and Accountability, Political Stability and Absence of Violence, Government Effectiveness, Regulatory Quality, Rule of Law and Control of Corruption)

Dummy = 1 in the presence of conflict in the country of origin, 0 otherwise

Calculated as the total number of natural disasters in a given year

\section{CRS-OECD DAC}

World Bank

World Bank

World Development Indicators, World Bank

\author{
UCDP Monadic Conflict Onset and \\ Incidence \\ Dataset
}

International Disaster Database, Centre for Research on the Epidemiology of Disasters 
TABLE A4 (Continued)

\begin{tabular}{|c|c|c|}
\hline Variable & Short description & Source \\
\hline $\begin{array}{l}\text { UN Votes Affinity } \\
\text { Index (d to o) }\end{array}$ & $\begin{array}{l}\text { Values for the Affinity index S3UN using } 3 \\
\text { category vote data ( } 1 \text { = 'yes' or approval for } \\
\text { an issue; } 2 \text { = abstain, } 3=\text { =no' or disapproval } \\
\text { for an issue.) }\end{array}$ & $\begin{array}{l}\text { Voeten, Erik; Strezhnev, Anton; Bailey, } \\
\text { Michael, 2009, “United Nations General } \\
\text { Assembly Voting Data”, https://doi.org/ } \\
\text { 10.7910/DVN/LEJUQZ, Harvard } \\
\text { Dataverse (updated version) }\end{array}$ \\
\hline $\begin{array}{l}\text { Log trade flows } \\
\text { (d to o) }\end{array}$ & $\begin{array}{c}\text { Trade flows in current US\$ from destination to } \\
\text { origin }\end{array}$ & BACI, CEPII \\
\hline
\end{tabular}

Instrumental variable analysis

Govt.

Government Fractionalization Index

fractionalization

Database of Political Institutions 2015.

Probability of receiving aid

For each dyad, it is calculated as the number of Inter-American Development Bank

years for which there's a positive ODA flow

CRS-OECD DAC over total number of years in the sample.

\section{Mechanisms \\ Doctors (per 10000 people)}
Nurses and midwifery personnel (per 10000 people)

Includes generalists, specialist medical practitioners and medical doctors not further defined, in the given national and/or subnational area. Depending on the nature of the original data source may include practising (active) physicians only or all registered physicians.

Number of nursing and midwifery personnel includes nursing personnel and midwifery personnel in the given national and/or subnational area. Depending on the nature of the original data source may include practising (active) nursing and midwifery personnel only or all registered nursing and midwifery personnel

\section{Immunization \\ Child immunization, DPT, measures the percentage of children ages 12-23 months who received DPT vaccinations before \\ 12 months or at any time before the survey. A child is considered adequately immunized against diphtheria, pertussis (or whooping cough), and tetanus (DPT) after receiving three doses of vaccine.} measles

Child immunization, measles, measures the percentage of children ages 12-23 months who received the measles vaccination before 12 months or at any time before the survey. A child is considered adequately immunized against measles after receiving one dose of vaccine.

Hospital beds (per $\quad \begin{gathered}\text { Hospital beds include inpatient beds available in } \\ 10000 \text { people) }\end{gathered}$
public, private, general, and specialized
hospitals and rehabilitation centres. In most
cases beds for both acute and chronic care
are included.

\section{World Health Organization}

World Health Organization

World Health Organization

World Health Organization

World Health Organization 
TABLE A5 Summary statistics

\begin{tabular}{|c|c|c|c|}
\hline Variable & Destination & $\begin{array}{l}\text { Nurses } \\
\text { All }\end{array}$ & $\begin{array}{l}\text { Doctors } \\
\text { All }\end{array}$ \\
\hline \multicolumn{4}{|c|}{ Emigration rate (o to d) } \\
\hline & Mean & 0.0008794 & 0.0011317 \\
\hline & St. Dev. & 0.0035844 & 0.0033195 \\
\hline \multicolumn{4}{|c|}{ Per capita health ODA (o) } \\
\hline & Mean & 2.367332 & 2.257906 \\
\hline & St. Dev. & 3.161005 & 3.003967 \\
\hline \multicolumn{4}{|c|}{ GDP per capita (o) } \\
\hline & Mean & 8803.38 & 9605.757 \\
\hline & St. Dev. & 6235.072 & 6610.046 \\
\hline \multicolumn{4}{|c|}{ Diaspora (o to d) } \\
\hline & Mean & 156928.6 & 93581.3 \\
\hline & St. Dev. & 769636.9 & 589544.6 \\
\hline \multicolumn{4}{|c|}{ Conflict (o) } \\
\hline & Mean & 0.2581661 & 0.2607705 \\
\hline & St. Dev. & 0.437712 & 0.439105 \\
\hline \multicolumn{4}{|c|}{ Natural Disasters (o) } \\
\hline & Mean & 3.884691 & 3.310007 \\
\hline & St. Dev. & 6.321231 & 5.38602 \\
\hline
\end{tabular}

Note: Means and standard deviation refer to Column 5 of Tables 1 and 2, respectively.

TAB LE A6 Alternative treatment of missing values in dependent variable

\begin{tabular}{|c|c|c|}
\hline \multirow{5}{*}{$\begin{array}{l}\text { Estimator } \\
\text { Dep. variable } \\
\text { Sample destinations }\end{array}$} & \multirow{3}{*}{$\begin{array}{l}\text { (1) } \\
\text { Nurses } \\
\text { PPML }\end{array}$} & \multirow{2}{*}{$\begin{array}{l}(2) \\
\text { Doctors }\end{array}$} \\
\hline & & \\
\hline & & PPML \\
\hline & Migration rate & Migration rate \\
\hline & Whole & Whole \\
\hline Log health ODA pc (o) & $-0.094^{*}(-2.14)$ & $-0.094^{*}(-2.47)$ \\
\hline Log GDP pc const. \$ PPP (o) & $-2.134^{* * *}(-7.44)$ & $-0.644^{*}(-2.23)$ \\
\hline$N$ & 2541 & 4387 \\
\hline Destination-year FE & $x$ & $x$ \\
\hline Origin-destination FE & $x$ & $x$ \\
\hline Destinations & 18 & 23 \\
\hline Origins & 108 & 107 \\
\hline$\%$ Zeros & $23.6 \%$ & $16.7 \%$ \\
\hline
\end{tabular}

Note: $z$ statistics are in parentheses. Robust standard errors are multiway clustered by donor, recipient and year. Migration rate is calculated using annual bilateral flows of nurses/doctors emigration over nurses/doctors population. Missing values of nurses/doctors population are linearly interpolated when possible, or imputed by letting the number of nurses vary proportionally to country's total population.

Abbreviations: FE, fixed effect; ODA, Official Development Assistance; PPP, purchasing power parity; PPML, PseudoPoisson maximum likelihood.

${ }^{*} p<0.05 .{ }^{* *} p<0.01 .{ }^{* * *} p<0.001$. 